\title{
EFFECTS OF STORM PATHS ON PRECIPITATION CHEMISTRY, AND VARIATIONS OF WITHIN- STORM CHEMISTRY DURING SELECTED STORMS IN CENTRAL MASSACHUSETTS, 1986-87
}

\section{BY JOHN C. RISLEY and JAMES B. SHANLEY}

U.S. GEOLOGICAL SURVEY

Water-Resources Investigations Report 94-4084

Prepared in cooperation with the COMMONWEALTH OF MASSACHUSETTS

DEPARTMENT OF ENVIRONMENTAL PROTECTION,

DIVISION OF WATER POLLUTION CONTROL

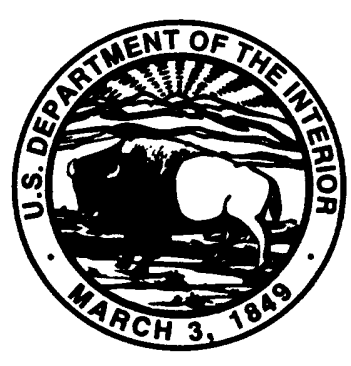

Marlborough, Massachusetts 


\section{U.S. DEPARTMENT OF THE INTERIOR BRUCE BABBITT, Secretary}

U.S. GEOLOGICAL SURVEY

Gordon P. Eaton, Director

For additional information write to:

District Chief

U.S. Geological Survey

Water Resources Division

Massachusetts-Rhode Island District

28 Lord Road, Suite 280

Marlborough, MA 01752
Copies of this report can be purchased from:

U.S. Geological Survey Earth Science Information Center Open-File Reports Section Box 25286, MS 517 Denver Federal Center Denver, CO 80225 


\section{CONTENTS}

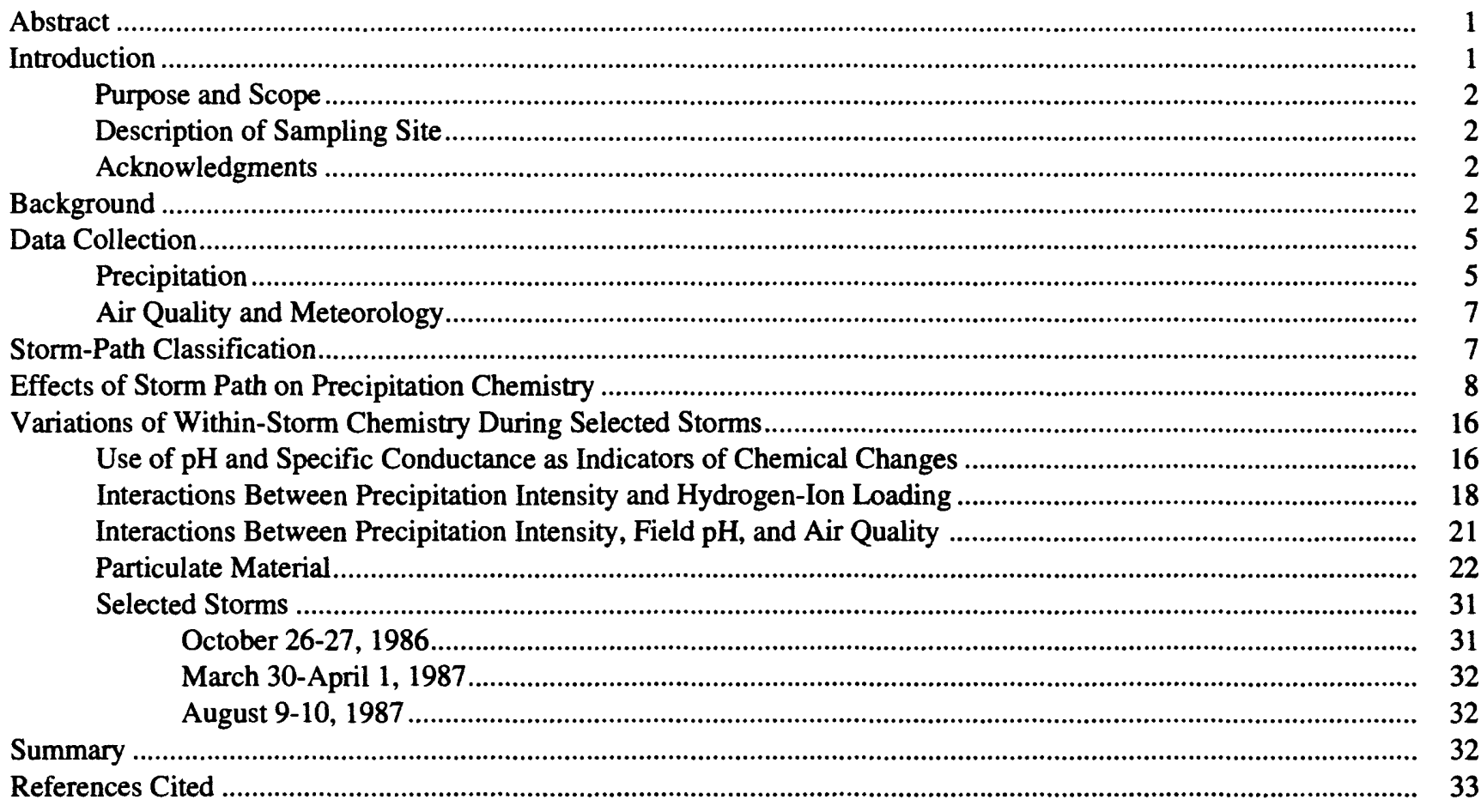

\section{FIGURES}

1. Map showing location of acidic precipitation sampling site, Quabbin Reservoir, central Massachusetts ..

2. Diagram showing within-storm precipitation sampler used for sample collection at Quabbin Reservoir, central Massachusetts

3. Map showing typical configuration of frontal storms associated with a low-pressure system in the continental United States

4. Generalized section through an advancing $(A)$ warm and $(B)$ cold fronts .

5. Map showing typical storm paths to the Northeast in the continental United States............................................. 11

6,7. Graphs showing:

6. Precipitation depth, specific conductance, and chemical-constituent concentrations from continental and coastal storms, Quabbin Reservoir, central Massachusetts.

7. Chemical-constituent loads from continental and coastal storms, Quabbin Reservoir, central Massachusetts.

8,9. Graphs showing relation, for Quabbin Reservoir, central Massachusetts, between log-transformed specific conductance and:

8. $\mathrm{pH}$ in composite storm samples

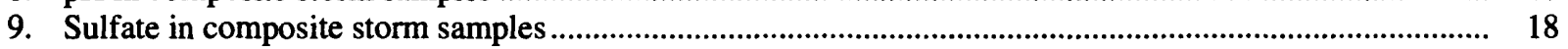

10,11. Graphs showing:

10. Relations between cumulative precipitation depth and cumulative hydrogen-ion loads with time and with each other for selected storms, Quabbin Reservoir, central Massachusetts.

11. Precipitation, surface-air temperature and dewpoint, surface-atmospheric sulfur dioxide and nitrogen dioxide, and pH for selected storms, Quabbin Reservoir, central Massachusetts. 


\section{TABLES}

1. Common-chemical and trace-element constituents and corresponding detection limits for chemical analysis

2. Air quality and meteorological characteristics measured at the Quabbin Hill monitoring station, central Massachusetts

3. Classification of 31 storms, Quabbin Reservoir, central Massachusetts, 1986-87

4. Mean, standard deviation, and skewness of precipitation depth, specific conductance, and chemicalconstituent concentrations from continental and coastal storms, Quabbin Reservoir, central Massachusetts

5. Mean, standard deviation, and skewness of chemical-constituent loads from continental and coastal storms, Quabbin Reservoir, central Massachusetts.

6. Results of Mann-Whitney nonparametric test of equivalent means of precipitation depth, specific conductance, and chemical-constituent concentrations for continental and coastal storms, Quabbin Reservoir, central Massachusetts

7. Results of Mann-Whitney nonparametric test of equivalent means of chemical-constituent loads for continental and coastal storms, Quabbin Reservoir, central Massachusetts.

8. Comparison of $\mathrm{pH}$ and specific conductance as surrogates of solute concentrations in 31 composite storm samples from Quabbin Reservoir, central Massachusetts.

9. Results of particulate materials analysis for three continental storms, Quabbin Reservoir, central Massachusetts

\section{CONVERSION FACTORS, VERTICAL DATUM, AND WATER-QUALITY INFORMATION}

\begin{tabular}{rll}
\hline \multicolumn{1}{c}{ Multiply } & by & To obtain \\
\hline kilometer $(\mathrm{km})$ & 0.6214 & mile \\
kilometer per hour $(\mathrm{km} / \mathrm{h})$ & 0.6214 & mile per hour $(\mathrm{mi} / \mathrm{h})$ \\
$\operatorname{liter}(\mathrm{L})$ & 33.82 & ounce, fluid \\
meter $(\mathrm{m})$ & 3.281 & foot \\
micrometer $(\mu \mathrm{m})$ & 0.0000394 & inch \\
milliliter $(\mathrm{mL})$ & 0.0338 & ounce, fluid \\
millimeter $(\mathrm{mm})$ & 0.03937 & inch \\
\hline
\end{tabular}

Air temperature is given in degrees Fahrenheit $\left({ }^{\circ} \mathrm{F}\right)$, which can be converted to degrees Celsius $\left({ }^{\circ} \mathrm{C}\right)$ by the following equation:

$$
{ }^{\circ} \mathrm{C}=\left({ }^{\circ} \mathrm{F}-32\right) / 1.8 \text {. }
$$

\section{Vertical Datum}

Sea level: In this report, "sea level" refers to the National Geodetic Vertical Datum of 1929--a geodetic vertical datum derived from a general adjustment of the first-order level nets of the United States and Canada, formerly called Sea Level of 1929.

\section{Water-Quality Information}

Chemical concentration is given in units of milligrams per liter $(\mathrm{mg} / \mathrm{L})$ or micrograms per liter $(\mu \mathrm{g} / \mathrm{L})$. Milligrams and micrograms per liter are units expressing the mass of the solute per unit volume (liter) of water. One thousand micrograms per liter is equivalent to 1 milligram per liter. Micrograms per liter is equivalent to "parts per billion." Milligrams per liter is equivalent to "parts per million." Chemical concentration is also given in units of milligrams per kilograms $(\mathrm{mg} / \mathrm{kg})$. One milligram per kilogram is equivalent to 1 microgram per gram. Milligram per kilogram is equivalent to "parts per million." 


\title{
Effects of Storm Paths on Precipitation Chemistry, and Variations of Within-Storm Chemistry During Selected Storms in Central Massachusetts, 1986-87
}

\author{
By John C. Risley and James B. Shanley
}

\begin{abstract}
Composite samples of precipitation from 31 storms were collected and analyzed for $\mathrm{pH}$, specific conductance, concentrations of common chemical constituents, and particulate matter from October 1986 through December 1987 at a site near Quabbin Reservoir in central Massachusetts. As classified on the basis of daily weather maps, 24 storms had a continental path west of the Appalachian Mountains. The remaining seven storms had a coastal path east of the Appalachian Mountains along the coast of the Atlantic Ocean. Precipitation from the continental storms was more acidic than that from coastal storms according to a nonparametric statistical comparison. Because the continental storms had less precipitation depth, the loads of hydrogen ions and other common chemical constituents from both groups were not statistically different.
\end{abstract}

The variability of within-storm precipitation chemistry was evaluated for 8 of the 31 storms. Cumulative incremental hydrogen-ion loads during each storm were compared with cumulative precipitation. The $\mathrm{pH}$ of the storm composite samples ranged from 3.9 to 5.1. Seven of the storms showed evidence of suspended-particulate removal at levels between the cloud layer and the land surface during their early stages. The remaining storm, also the most acidic, showed evidence of suspended-particulate removal within the cloud layer, as indicated by a relatively constant $\mathrm{pH}$ throughout the storm. Specific conductance and hydrogen-ion concentration were adequate predictors of sulfate, nitrate, nitrite-plus-nitrate, and ammonium concentrations in the composite precipitation samples.
Atmospheric concentrations of sulfur dioxide and nitrogen dioxide before, during, and after storms were compared to within-storm values of $\mathrm{pH}$ and precipitation for the eight storms. Seven of the storms were characterized by decreased atmospheric concentrations of sulfur dioxide and nitrogen dioxide in the early stages of the storm. For three of the storms, atmospheric concentrations of sulfur dioxide and nitrogen dioxide were higher during the 24-hour period after the storm than the 24-hour period preceding the storm.

Particulate analysis was done on 0.4-micrometer filter membranes used in processing samples from three continental storms. Biotite was the predominant mineral in two of the storms. Other minerals detected were garnet, quartz, gypsum, hematite, epidote, ilmenite, eggonite, halite, rutile, and organic ash. The predominance of the large particle-size fraction (1-30 micrometers) indicates that the particulate materials probably were of local origin. All the filter membrane samples exhibited a mat of very fine-grained (less than 0.01 micrometer) polymeric organic material that bridged the filter pores.

\section{INTRODUCTION}

Assessment of precipitation chemistry is a necessary component of efforts to understand and improve the water quality of reservoirs, lakes, ponds, rivers, and ground water, because precipitation is the source of water to these bodies. Precipitation near the Quabbin Reservoir in central Massachusetts was studied in 1986 by the U.S. Geological Survey, (USGS) in cooperation with the Massachusetts Department of Environmental Protection, Division of Water Pollution Control, to improve the understanding of natural and human-influenced chemical characteristics of precipitation and the effects of storm paths on precipitation chemistry. Acidic deposition and 
its adverse effects on forest, agriculture, and fisheries in the Northeast have been widely documented in recent years (Cogbill and Likens, 1974; Cowling, 1982). Acidic deposition refers to acidic precipitation (popularly known as acid rain) and dry deposition.

\section{Purpose and Scope}

This report presents the results of a study that examined acidic precipitation in 31 storms that occurred near the Quabbin Reservoir during October 1986 through December 1987 (fig. 1). Specifically, the report describes (1) the effects of storm paths, either east or west of the Appalachian Mountains, on the precipitation chemistry of composite samples from all the storms, (2) changes in the concentrations of chemical constituents in incremental precipitation samples collected during eight storms, and (3) results of particulate analyses of samples from three storms.

Composite precipitation samples from all 31 storms were analyzed for common chemical constituents. Common chemical constituents included calcium, magnesium, sodium, potassium, sulfate, chloride, hydrogen, nitrate, nitrite plus nitrate, and ammonia. Within-storm hourly samples were collected during 8 of the 31 storms. Filter membranes used in processing precipitation samples from 3 of the 31 storms were analyzed for particulates. Continuous ambient air-quality and meteorological data were collected at the site by the Massachusetts Division of Air Quality.

\section{Description of Sampling Site}

Storm precipitation samples used in this study were collected at a site on Quabbin Hill, which is at the southern edge of the Quabbin Reservoir near Windsor Dam in central Massachusetts (fig. 1). The nearest population center is the town of Ware, about $8 \mathrm{~km}$ to the east-southeast. The nearest cities are Springfield (about $30 \mathrm{~km}$ southwest) and Worcester ( $40 \mathrm{~km}$ east). The altitudes of the reservoir and the summit of the hill are about 160 and $312 \mathrm{~m}$.

Quabbin Hill is in the State-owned Quabbin Reservoir Reservation. Because it is a source for public-water supply in eastern Massachusetts, the reservation is protected from development and public access. There are no point sources of contamination on the reservation. The site meets the National Acid Deposition Program's (NADP) criteria for acidic-deposition data- collection sites, which state that sites should be cleared in all directions of any obstruction greater than $\mathbf{3 0}$ degrees from the horizon.

\section{Acknowledgments}

The authors thank the Metropolitan District Commission for providing a site for collection of precipitation samples, the Massachusetts Division of Air Quality for providing hourly air quality and meteorological data, and meteorologist Brian Seely of the U.S. National Weather Service in Boston for his assistance in classifying the paths of 31 storms.

\section{BACKGROUND}

The surface layer of the atmosphere (within $1,000 \mathrm{~m}$ above land surface) contains water vapor, particulate matter, and various gaseous oxides originating from power-generation plants, smelters, refineries, incinerators, automobiles, and commercial- and homeheating systems. The predominant oxides are sulfur dioxide $\left(\mathrm{SO}_{2}\right)$, nitric oxide (NO), and nitrogen dioxide $\left(\mathrm{NO}_{2}\right)$. The atmosphere also may contain trace amounts of heavy metals including copper, lead, iron, manganese, and zinc from anthropogenic sources. Natural processes also contribute materials to the atmosphere, such as dust particles from wind erosion of the land surfaces and water vapor from evaporation and plant transpiration (Babich and others, 1980).

This mixture of gases, water vapor, and particulates in the atmosphere is in continual motion as the surrounding air mass moves over land formations and is agitated by convection currents caused by buoyancy differences within the air column. The mixture can remain in the atmosphere and be transported thousands of kilometers across land and sea surfaces (Babich and others, 1980). Most air masses entering the Northeast are a part of the west-to-east global-circulation pattern at the latitude range of 30 to $60^{\circ} \mathrm{N}$. These air masses include cold air from Canada and warmer, more humid air from the Gulf of Mexico and the subtropical waters off the southeastern United States. Most storms are caused by the interaction of these cold and warm air masses.

The chemical process of acidic precipitation begins when sunlight and water vapor convert gaseous oxides into acidic compounds through hydrolysis. 


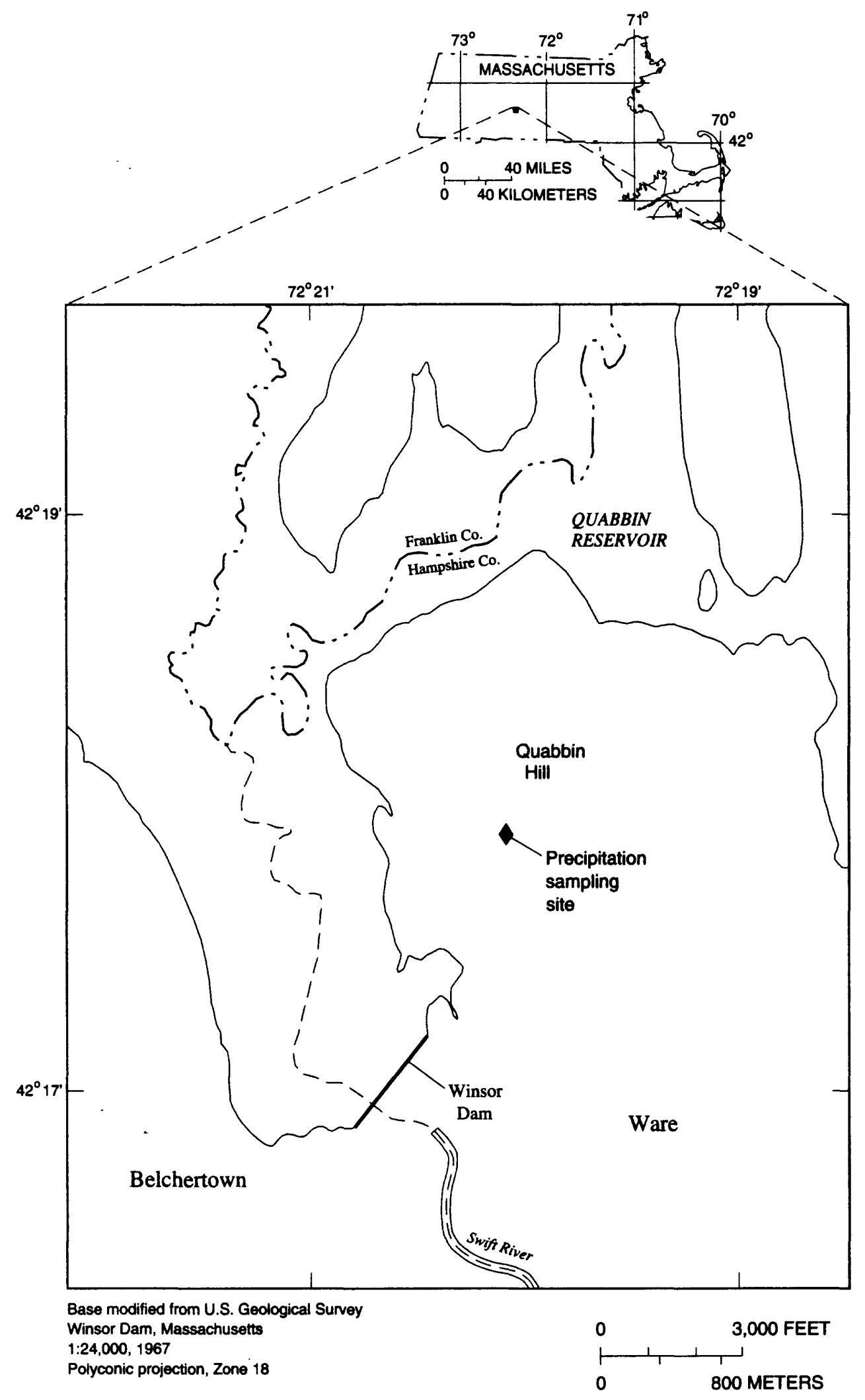

Figure 1. Location of acidic precipitation sampling site, Quabbin Reservoir, central Massachusetts. 
Sulfur and nitrogen dioxide are converted into sulfuric and nitric acids. This process is given for sulfur by the following equation:

$$
\mathrm{SO}_{2}+\frac{1}{2} \mathrm{O}_{2}+\mathrm{H}_{2} \mathrm{O} \leftrightarrow \mathrm{H}_{2} \mathrm{SO}_{4} .
$$

Suspended particulates in the atmosphere act as condensation nuclei for water vapor. The particulates also are removed from the atmosphere by their collision with and attachment to falling precipitation. In addition, as precipitation droplets are falling and growing, their surfaces sorb gases. These scavenging processes are collectively referred to as rainout when they occur in the cloud layer and washout when they occur in the atmosphere between the cloud layer and the land surface. Precipitation is considered by many to be an effective scrubber of the atmosphere. Washout is more predominant with small-volume storms and generally occurs in the early phase of the storm (Junge, 1963).

The acids ionize in water solution to produce hydrogen ions. The dissociation of sulfuric acid creates sulfate and hydrogen ions:

$$
\mathrm{H}_{2} \mathrm{SO}_{4} \leftrightarrow 2 \mathrm{H}^{+}+\mathrm{SO}_{4}^{2-} \text {. }
$$

The concentration of free hydrogen ions in solution is an indicator of acidity. $\mathrm{pH}$ is defined as the negative base- $10 \log$ of the hydrogen activity in moles per liter in solution. Low pH is an indication of high acidity. During many storms, precipitation $\mathrm{pH}$ is lowest in the early stages of the storms (Lindberg and others, 1979). This phenomenon may be an indication that most of the washout takes place during the early stages. As storm intensity increases, precipitation $\mathrm{pH}$ commonly increases because of the effect of dilution.

Acidic precipitation percolating into soils can adversely affect soil chemistry. The natural buffering capacity of a soil reflects the ability of its weathering and ion-exchange processes to consume hydrogen ions. With the continued addition of hydrogen ions to a soil, soil $\mathrm{pH}$ decreases and the buffering capacity of the soil is exceeded. When the concentration of hydrogen ions is high, common chemical constituents and metals such as calcium, sodium, magnesium, aluminum, iron, and manganese can be mobilized through cation exchange. These mobilized elements can be leached from the soil column, after which they can reprecipitate, reexchange, or move to underlying ground water. Much of the Northeast is composed of podzolic soils, which are characterized as acidic having a low cation-exchange capacity. These soils are the most susceptible of all soils to alteration by acidic precipitation (Babich and others, 1980).

Some researchers believe that acid deposition is causing the acceleration of chemical weathering rates of silicate materials (Babich and others, 1980). Such acceleration would increase the availability of potentially toxic metal cations, such as aluminum, lead, manganese, mercury, and nickel, to plant root systems. Commonly, uptake of these metals by plants can inhibit uptake of other needed plant nutrients. Yields of agricultural crops deficient in required plant nutrients generally are less than normal. The uptake of dissolved aluminum instead of dissolved calcium by tree roots has been postulated as a cause of red spruce dieback in the Northeast (Shortle and Smith, 1988). The decline is manifested by narrower tree-ring growth and premature death of various species of trees. Studies have shown that simulated acidic precipitation at $\mathrm{pH} 3$ or less may harm plant foliage. Birch seedlings exposed to an artificially acidified mist at $\mathrm{pH} 3$ or less decreased in growth and developed extensive foliage damage (Babich and others, 1980). The effects of acidic precipitation on freshwater-fish populations have been widely publicized. Toxic metals (in particular aluminum) that are mobilized in the soils and then enter freshwater bodies through runoff have been identified as the cause of fish die-off in the Northeast (Beamish and Van Loon, 1977).

Pure water in equilibrium with atmospheric carbon dioxide has a pH of 5.6; however, the natural background $\mathrm{pH}$ of precipitation in the Northeast is estimated to be near 5.0 (Schindler, 1988). Turk (1983) indicates that natural $\mathrm{pH}$ for precipitation can range from 4.5 to 5.6 depending on the quantity of naturally occurring nitrogen and sulfur compounds in the atmosphere. Massachusetts and other States of the Northeast have received precipitation with $\mathrm{pH}$ in the 4.0 to 4.5 range since 1955 (Cogbill and Likens, 1974; Likens and others, 1979; Cowling, 1982; and Glass and others, 1982).

Regional source apportionment of wet and dry (aerosol) acid deposition in Massachusetts has been investigated by Wolff (1989), and Wolff and Karsog (1989). The investigators analyzed daily ambient air samples from a study site in Lenox, Mass. for precursors (sulfate, sulfur dioxide, and nitrate) as well as for tracer species associated with particular sources. Although their study was based on only a 62-day period during summer 1984, they estimated that midwestern State sources accounted for 46 percent of the total 
nitrates and 58 percent of the total sulfates. Northeastern States accounted for the balance of the total nitrates and 18 percent of the sulfates. About 24 percent of the sulfates was attributed to background.

\section{DATA COLLECTION}

Study data included storm-precipitation samples collected by the USGS at the study site and surfacelevel air-quality monitor measurements collected by MDEP. All data-collection equipment were located in the same vicinity. Storm-precipitation samples were used in all three major components of the studyeffects of storm path on precipitation chemistry, variations of within-storm chemistry, and particulates. Surface-level air-quality data were used primarily in the second study component.

\section{Precipitation}

Three separate samplers were installed at the datacollection site. A Geotech Model 0650 Electronic Wetfall/Dryfall Precipitation Collector ${ }^{1}$ was used to collect composite samples from individual storms. A second Geotech precipitation collector, modified and connected to an ISCO sampler, was used to collect incremental samples of precipitation at timed intervals during each storm. A Belfort continuous-recording weighing bucket rain gage was used to record the quantity and time of precipitation. The 6- by 6-m equipment area was enclosed by a $1.2-\mathrm{m}$ high fence. The three units were mounted on separate wooden bases so that their precipitation-entry levels were about $2.1 \mathrm{~m}$ above land surface.

The Geotech sampler contains a wetfall bucket to collect precipitation and a dryfall bucket to collect dry particulate deposition. As mentioned previously, dry deposition was not collected in this study. During nonstorm periods, the wetfall bucket was covered with a motorized lid. The Geotech unit contains a sensing device consisting of a heated plate beneath a metal grid. Serving as the poles of the electrical circuit, the plate and the grid are separated by about $1 \mathrm{~mm}$ of air space. When a water droplet bridges the air space, the circuit is completed and the motorized lid moves from the wetfall bucket to the dryfall bucket. After the storm has ended,

\footnotetext{
${ }^{1}$ Any use of trade, product, or firm names in this publication is for descriptive purposes only and does not constitute endorsement by the U.S. Government.
}

the heated plate evaporates remaining water droplets. The circuit is broken, and the lid moves back to the wetfall bucket.

The second Geotech unit, attached to an ISCO sampling unit, was similar to the one described above, but with some modifications (fig. 2). The single wetfall bucket was replaced by three large funnels used to collect precipitation. The funnels provided an increased precipitation-collection area, which increased the volume of each sample. This method increased the likelihood that the volume of each discrete sample would be sufficient for chemical analysis. From $25.4 \mathrm{~mm}$ of rainfall, $3.96 \mathrm{~L}$ were collected. Tubes from the three funnels were joined to a single tube, which led to the ISCO unit. The sampler was activated at the beginning of the storm when the motorized lid was activated. The sampler contained a ring of twenty-four 1-L polyethylene sample bottles. The tube from the Geotech unit was connected to a nozzle, which rotated above the ring in position to fill each of the 24 bottles with precipitation from each time period. The timing sequence of the ISCO unit was programmed before each storm to collect samples at predetermined intervals. The length of the intervals was adjusted to optimize sample collection. An interval too short might not be long enough to collect a sufficient sample. However, using a longer interval increased the chance of the sample overflowing from the bottle. During most of the 31 storms, the first two bottles were

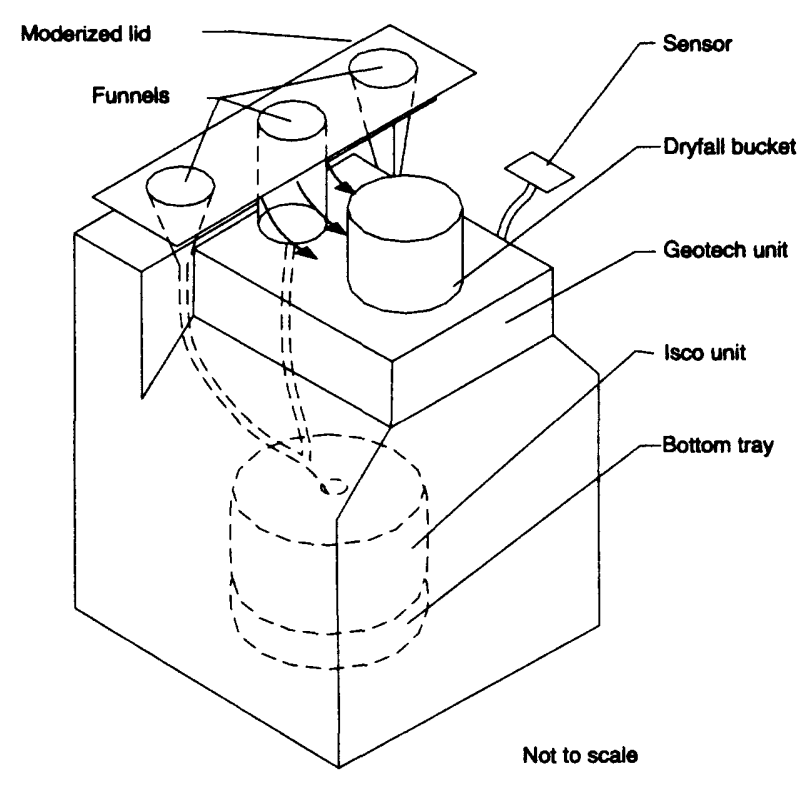

Figure 2. Within-storm precipitation sampler used for sample collection at Quabbin Reservoir, central Massachusetts. 
programmed to fill for 120 minutes each, bottles 3 through 20 were programmed to fill for 90 minutes each, and bottles 21 through 24 were programmed to fill for 120 minutes each. The combined Geotech and ISCO samplers were enclosed in plywood and were insulated. The enclosed box was equipped with heat lamps to prevent freezing of the tubes and the sample bottles. Side heat chimneys were added to keep the outer funnels from freezing.

The weighing-bucket rain gage provided a continuous recording of storms. The rain gage was configured to collect as much as $304.8 \mathrm{~mm}$ of precipitation and record the timing of rainfall on a 2-day chart. This configuration allowed the determination of starting and ending times to the nearest 0.5 hour and precipitation amounts to the nearest $0.254 \mathrm{~mm}$. The rain gage was protected by an Altar aluminum skirt to reduce wind shear and ensure a representative sampling during the storm. The diameter of the skirt was $1.2 \mathrm{~m}$.

The precipitation samples usually were removed from the samplers within 12 hours after the end of each storm. The polyethylene wetfall bucket in the composite sampler was replaced with a clean bucket. The base containing the ring of 24 sample bottles was lifted from the incremental sampler, and each bottle was capped. A new base containing 24 clean bottles was then placed into the sampler. All sample bottles, buckets and tubing were cleaned by triple rinsing with deionized water. The strip chart on the rain gage also was changed.

The sample bottles were taken to the field laboratory at the Massachusetts office of the USGS. Each sample bottle was weighed to determine sample volume. If the bottles contained a minimum of $50 \mathrm{~mL}$ of sample, $\mathrm{pH}$ and specific conductance were determined.

Selected samples were sent to the USGS laboratory in Denver, Colo. All samples were analyzed for the common chemical constituents listed in table 1 . The number of chemical analyses that were done on the samples depended on the volume of sample available. Usually, a minimum of $200 \mathrm{~mL}$ is needed to determine the common chemical constituents. An additional $800 \mathrm{~mL}$ is needed to determine trace elements listed in table 1. Composite samples, which represented the entire storm, usually were of sufficient volume for analysis of common and metal constituents. Incremental samples however generally had to be combined to increase their volume. The number of samples analyzed for trace elements were not sufficient for subsequent statistical analyses.
Before a sample was sent to Denver, a lab schedule of specific analyses to be done on that sample was determined. Aliquots of sample were filtered, and various fixing agents were added before shipping. The samples were filtered through polycarbonate membranes, which were $47 \mathrm{~mm}$ in diameter with $0.4-\mu \mathrm{m}$ pore-size openings. Five membranes from 3 of the 31 storms were

Table 1. Common-chemical and trace-element constituents and corresponding detection limits for chemical analysis

[Different detection limits were the result of using different analytical methods to analyze the same constituent. $\mathrm{mg} / \mathrm{L}$, milligram per liter; $\mu \mathrm{g} / \mathrm{L}$, microgram per liter]

\begin{tabular}{lr}
\hline \multicolumn{1}{c}{ Constituent } & Detection limit \\
\hline \multicolumn{2}{c}{ COMMON CHEMICALS (mg/L) } \\
\hline Calcium & 0.01 or 0.02 \\
Magnesium & 0.01 \\
Sodium & 0.01 or 0.2 \\
Potassium & 0.01 \\
Sulfate & 0.01 or 0.2 \\
Chloride & 0.01 or 0.2 \\
Fluoride & 0.01 \\
Bromide & 0.01 or 0.1 \\
Silica & 0.01 \\
Nitrate, dissolved as N & 0.01 or 0.05 \\
Nitrogen, ammonia, dissolved as $\mathrm{NH}_{4}$ & $0.001,0.002$, \\
& or 0.01 \\
Phosphorus, dissolved as P & 0.001 \\
Phosphorus, dissolved orthophosphate, as $\mathrm{P}$ & 0.001 \\
\hline
\end{tabular}

TRACE ELEMENTS $(\mu \mathrm{g} / \mathrm{L})$

$\begin{array}{lr}\text { Aluminum } & 10 \\ \text { Antimony } & 1 \\ \text { Arsenic } & 1 \\ \text { Barium } & 2 \\ \text { Beryllium } & 0.5 \\ \text { Boron } & 20 \\ \text { Cadmium } & 1 \\ \text { Chromium } & 1 \\ \text { Cobalt } & 3 \\ \text { Copper } & 10 \\ \text { Iron } & 3 \\ \text { Lead } & 0.08 \text { or } 10 \\ \text { Lithium } & 4 \\ \text { Manganese } & 1 \\ \text { Mercury } & 0.1 \\ \text { Molybdenum } & 10 \\ \text { Nickel } & 1 \\ \text { Selenium } & 1 \\ \text { Strontium } & 0.5 \\ \text { Vanadium } & 1 \text { or } 6 \\ \text { Zinc } & 3\end{array}$


analyzed for particulate content. These included three composite storm samples and two incremental samples obtained during one of the three storms. The filtermembrane samples were scanned by means of standard optical microscopy. Identification of a particular mineral was verified (or refined) by Emissive Dispersive Xray (EDX) analysis. The EDX analysis identified the garnet in some samples as almandite. Point counts were made for all samples to determine the relative and absolute distributions of the minerals present. Particles in 20 grids, 20 by $20 \mu \mathrm{m}$, were counted, and the results were expressed in thousands of particles per square centimeter. Variability among grids was small; thus, this sample size was believed to be adequate.

\section{Air Quality and Meteorology}

An air-quality monitoring station about $50 \mathrm{~m}$ west of the precipitation collection site on Quabbin Hill has been in operation since 1985 by the Massachusetts Department of Environmental Protection as part of the NADP. The air-quality and meteorological characteristics measured at the station are listed in table 2. Several characteristics have been measured either hourly or daily since the station began operating.

\section{STORM-PATH CLASSIFICATION}

A major objective in this study was to examine possible relations between storm system paths and the chemical quality of the precipitation. By use of an appropriate classification of storm paths, statistical tests were used to show if the concentrations of chemical constituents in the water samples of the storm groups were significantly different.

In Massachusetts, most storms, except for thundershowers, are the result of frontal activity. Frontal storms, generally associated with low-pressure systems, are the result of the interaction of warm moist and cool

Table 2. Air quality and meteorological characteristics measured at the Quabbin Hill monitoring station, central Massachusetts

[Data from Chas T. Main, Inc., 1986. Abbreviations: ppm, parts per million; $\mu \mathrm{g} / \mathrm{m}^{3}$, microgram per cubic meter (mass per unit volume concentration); $\mu \mathrm{m}$, micrometer; $\mathrm{m}$, meters; mph, miles per hour; ${ }^{\circ} \mathrm{F}$, degrees Fahrenheit; mb, millibars; Lpm, Langleys per minute]

\begin{tabular}{|c|c|c|c|}
\hline $\begin{array}{c}\text { Measured } \\
\text { characteristics }\end{array}$ & $\begin{array}{c}\text { Derived } \\
\text { characteristics }\end{array}$ & $\begin{array}{c}\text { Units of } \\
\text { measurement }\end{array}$ & $\begin{array}{l}\text { Sampling } \\
\text { frequency }\end{array}$ \\
\hline Sulfur dioxide $\left(\mathrm{SO}_{2}\right)$ & $\mathrm{SO}_{2}$ & ppm & Continuous 1 \\
\hline Oxides of nitrogen (NO-NO$-\mathrm{NO}_{\mathbf{x}}$ ) & $\mathrm{NO}-\mathrm{NO}_{2}-\mathrm{NO}_{\mathrm{x}}$ & ppm & Continuous \\
\hline Ozone $\left(\mathrm{O}_{3}\right)$ & $\mathrm{O}_{3}$ & $\mathrm{ppm}$ & Continuous \\
\hline \multirow[t]{3}{*}{ Total suspended particulate (TSP) } & TS̆P & $\mu \mathrm{g} / \mathrm{m}^{3}$ & Daily \\
\hline & Sulfate $\left(\mathrm{SO}_{4}\right)^{2}$ & $\mu \mathrm{g} / \mathrm{m}^{3}$ & Daily \\
\hline & Nitrate $\left(\mathrm{NO}_{3}\right)^{2}$ & $\mu \mathrm{g} / \mathrm{m}^{3}$ & Daily \\
\hline Inhalable particulate (IP) $(2.5-10 \mu \mathrm{m})$ & $\mathrm{IP}_{10}$ & $\mu \mathrm{g} / \mathrm{m}^{3}$ & Daily \\
\hline Inhalable particulate (IP) $(0-2.5 \mu \mathrm{m})$ & $\mathrm{IP}_{2.5}$ & $\mu \mathrm{g} / \mathrm{m}^{3}$ & Daily \\
\hline Visibility (VSBY), nonheated & VSBY $1^{3}$ & $\mathrm{~m}$ & Continuous \\
\hline Visibility (VSBY), heated & VSBY $2^{4}$ & $\mathrm{~m}$ & Continuous \\
\hline \multirow[t]{3}{*}{ Wind direction (WD) } & Vector WD & Degrees from true north & Continuous \\
\hline & Scalar WD & Degrees from true north & Continuous \\
\hline & Sigma Theta ${ }^{5}$ & Degrees & \\
\hline \multirow[t]{2}{*}{ Wind speed (WS) } & Vector WS & $\mathrm{mph}$ & Continuous \\
\hline & Scalar WS & $\mathrm{mph}$ & Continuous \\
\hline Temperature (TEMP) & TEMP & ${ }^{\circ} \mathrm{F}$ & Continuous \\
\hline Relative humidity (RH) & RH & Percent & Continuous \\
\hline Barometric pressure (BP) & BP & $\mathrm{mb}$ & Continuous \\
\hline Solar radiation & Solar radiation ${ }^{6}$ & Lpm & Continuous \\
\hline
\end{tabular}

${ }^{1}$ Data was collected on strip charts on a continual basis.

${ }^{2} \mathrm{SO}_{4}$ and $\mathrm{NO}_{3}$ concentrations determined by laboratory analyses.

${ }^{3}$ VSBY 1 scattering coefficient.

${ }^{4}$ VSBY 2 visual range; measurements terminated in November 1985.

${ }^{5}$ Sigma Theta is standard deviation of wind-direction fluctuations about the mean.

${ }^{6}$ Solar radiation measurements commenced in September 1985. 
dry air masses (fig. 3). In these storms, the cooler air forces moist air upward, releasing the moisture from the warm air in the form of clouds and precipitation. These air masses, generally originating in the Gulf of Mexico and Canada vary seasonally in intensity with the greatest variation occurring in the winter season. The warm fronts are the leading edges of the warm air masses and cold fronts are the leading edge of cold air (fig. 4).

Most of the storms follow a path on the west side of the Appalachians and through the Midwest. They are generally steered by the upper air westerly winds (fig. 5). The path of the low-pressure systems passing through the Northeast commonly is affected by the position of the jet stream. Some storms follow paths on the eastern side of the Appalachians. This circulation pattern draws moisture from the Gulf of Mexico or the Caribbean.

Although the path of frontal systems contributing to a storm is possible to determine, ascertaining the origin of chemical constituents in the precipitation contributed by the storm and in the precipitation water itself is more difficult. Some of the long-range transported chemical constituents present in precipitation were assumed to accumulate along the path of the air masses. (In this report, long-range transported chemical constituents are defined as constituents originating in regions outside of Massachusetts and Connecticut.) A classification system based on storm path should be a means of differentiating the chemical constituents in storms by the direction of their possible origin.

With the assistance of a meteorologist from the U.S. National Weather Service in Boston, daily continental weather maps were used to determine paths of storm systems contributing to the 31 storms documented in this study. The storm systems were classified as either continental (following paths west of the Appalachians) or coastal (following paths east of the Appalachians). These paths are shown in figure 5. After evaluation of the 31 storms, 24 were classified as continental and 7 as coastal (table 3 ).

\section{EFFECTS OF STORM PATH ON PRECIPITATION CHEMISTRY}

Precipitation depth and specific conductance values for the composite samples from the continental and the coastal storms were compared (fig. 6). Chemical constituents in the composite samples from both storm groups were compared on the basis of both concentration and load (figs. 6-7). Summary statistics for precipitation depth, specific conductance, and chemical constituent concentration and load are listed in tables 4 and 5. The means of the characteristics from both groups were statistically tested to determine if the two groups were significantly different.

Comparison of chemical constituents from the two storm groups on the basis of concentration alone is appropriate if the mean storm volumes of both groups are approximately equal; however, differentiation between rainout and washout processes requires comparison of chemical-constituent loads in addition to concentrations. If the mean storm volume is significantly greater for one storm group, reporting the chemical constituents as load will offset the effect of dilution (which would occur during washout conditions).

Data from the storm groups indicate that the mean precipitation depth of the coastal storms is greater than the mean precipitation depth of the continental storms (fig. 6 and table 4). The variances for most of the constituents in either concentration or load form are greater for continental storms than for coastal storms (figs. 6-7).

On a charge-equivalent basis, the hydrogen ion is typically the dominant cation in precipitation in the eastern United States (Drever, 1988). Hydrogen-ion concentration and specific conductance are highly correlated. Other chemical constituents generally are correlated with hydrogen-ion concentration. In general, the means of hydrogen-ion concentration and specific conductance, as well as most other chemical constituents (also in concentration form), are higher for continental storms than for coastal storms. On a load basis, however, the two groups are more similar (table 5, fig. 7).

Because of the limited number of samples in the coastal storm group and non-normality of the data, use of the t-test as a method of comparing the means of two groups was not possible. The Mann-Whitney test is a nonparametric alternative (Iman and Conover, 1983). Although the Mann-Whitney test is not as powerful as the $\mathrm{t}$-test, the Mann-Whitney test is a means of comparison testing for small groups of data whose test distribution characteristics are unknown. 


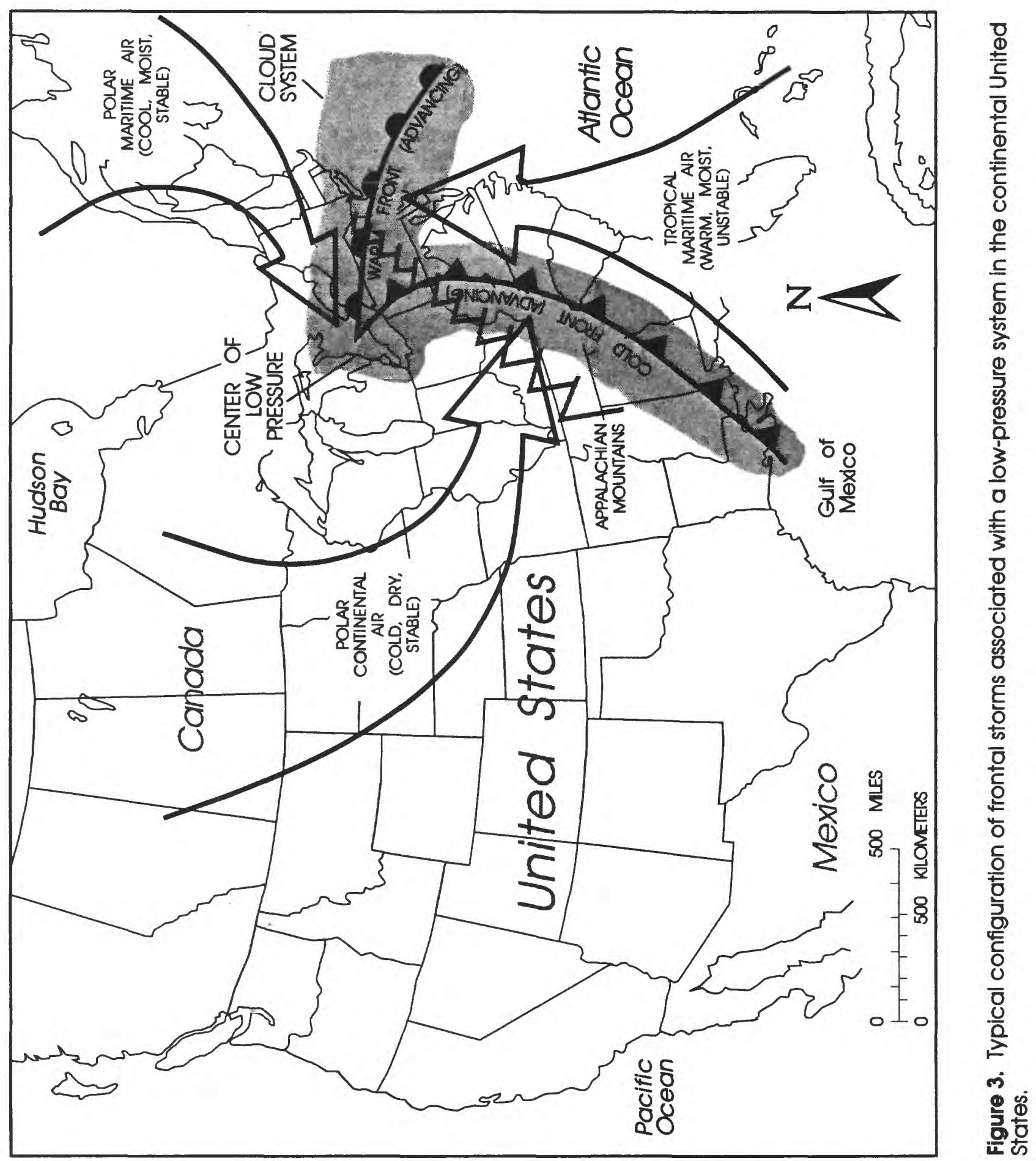




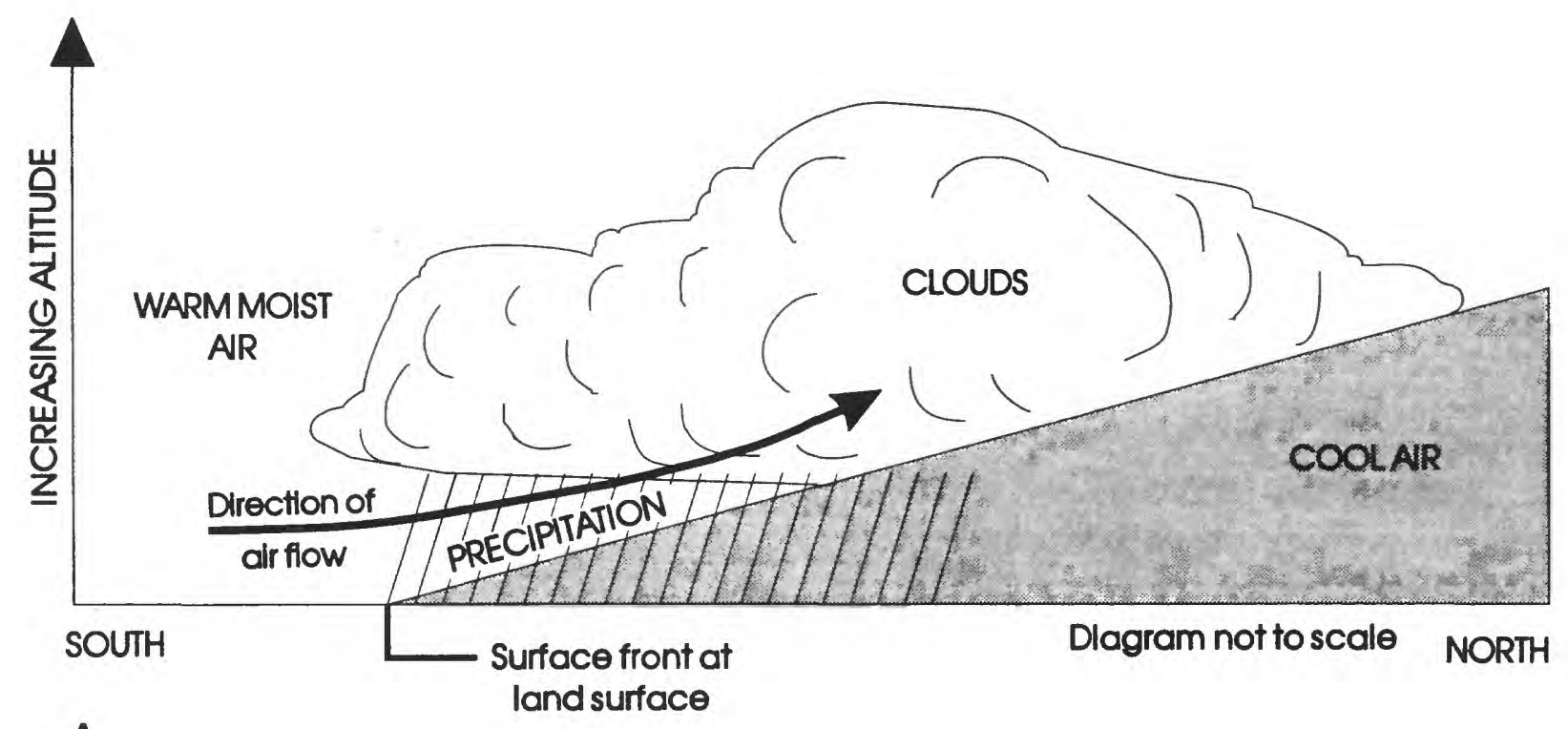

A

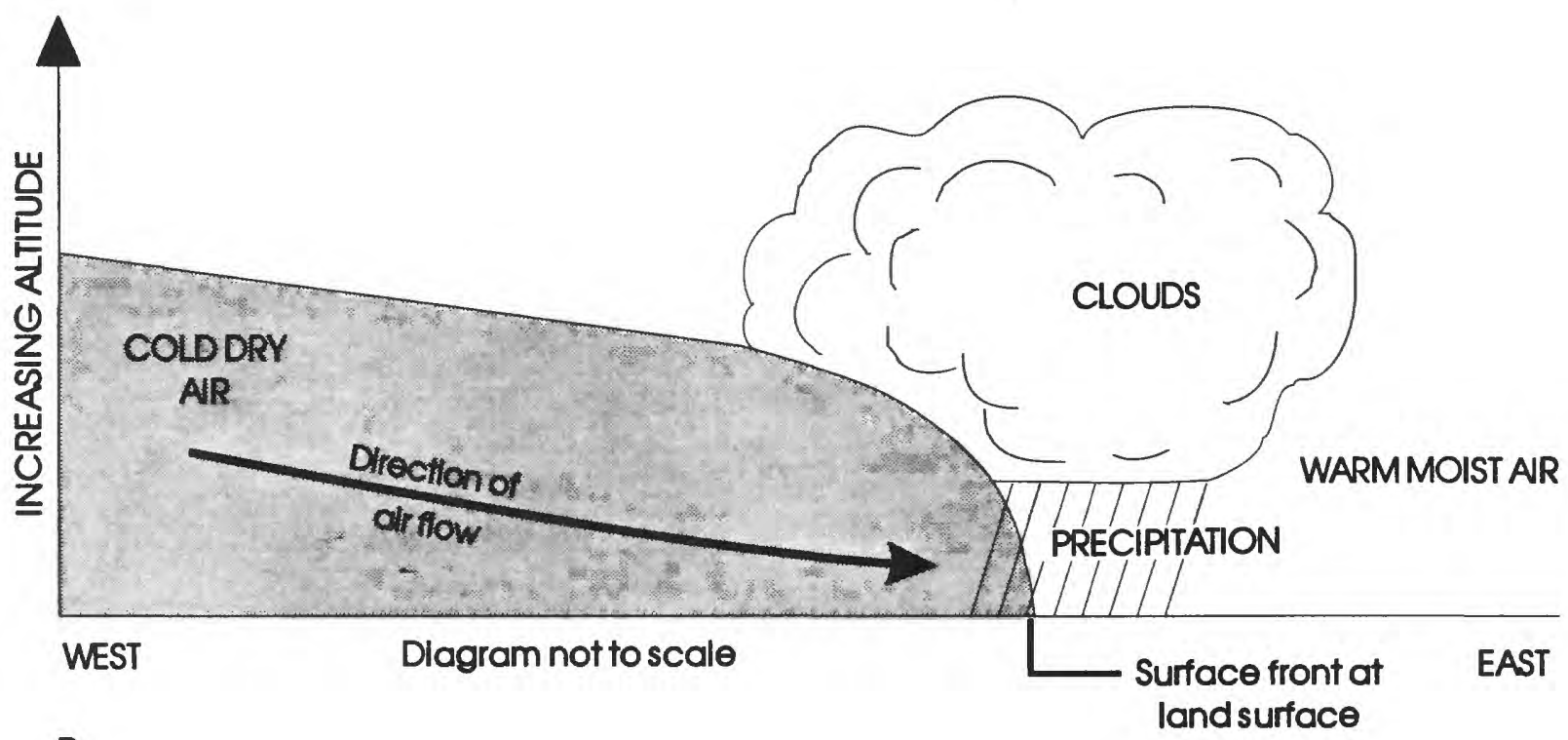

B.

Figure 4. Generalized section through an advancing $(A)$ warm and $(B)$ cold fronts. 


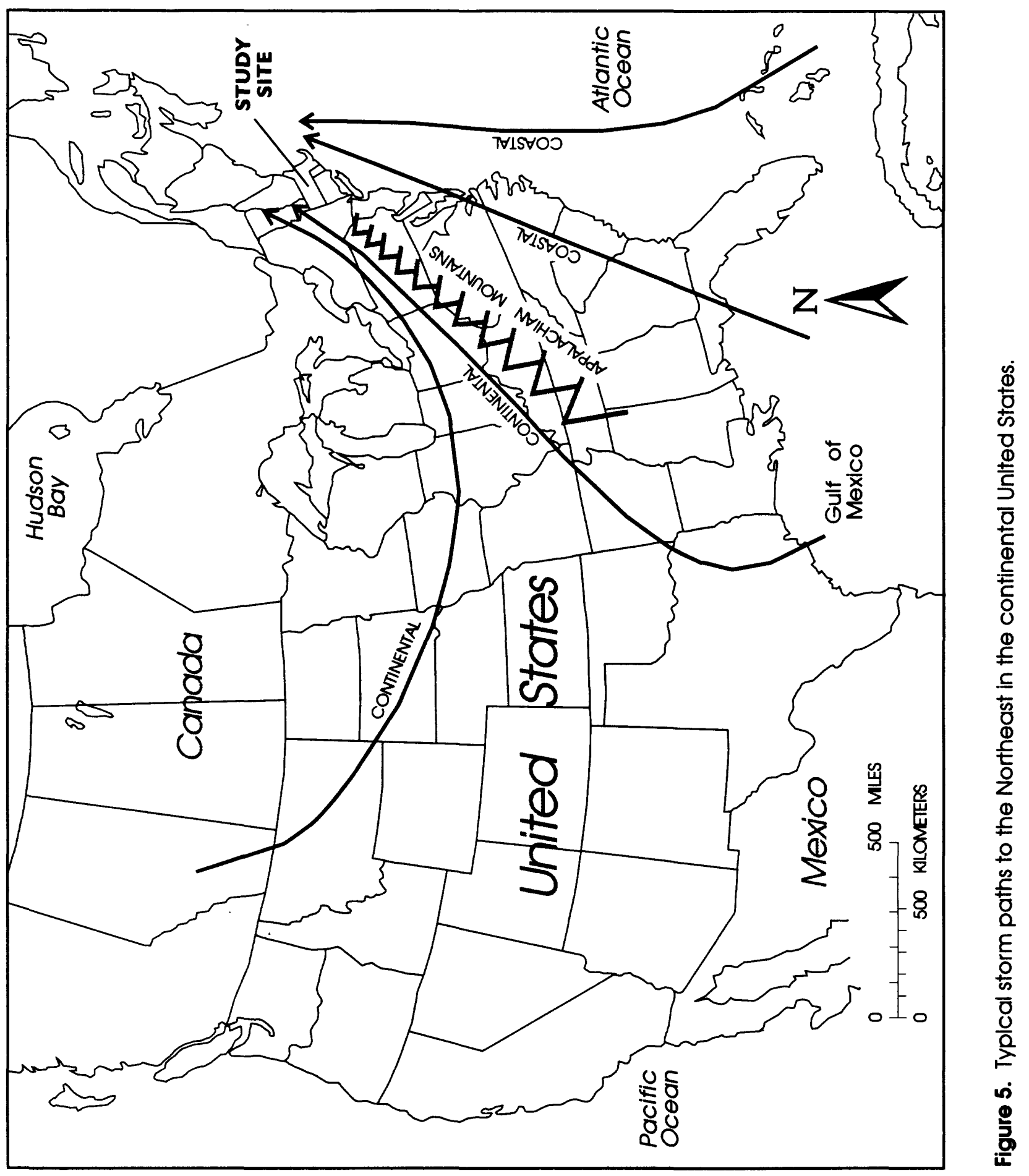



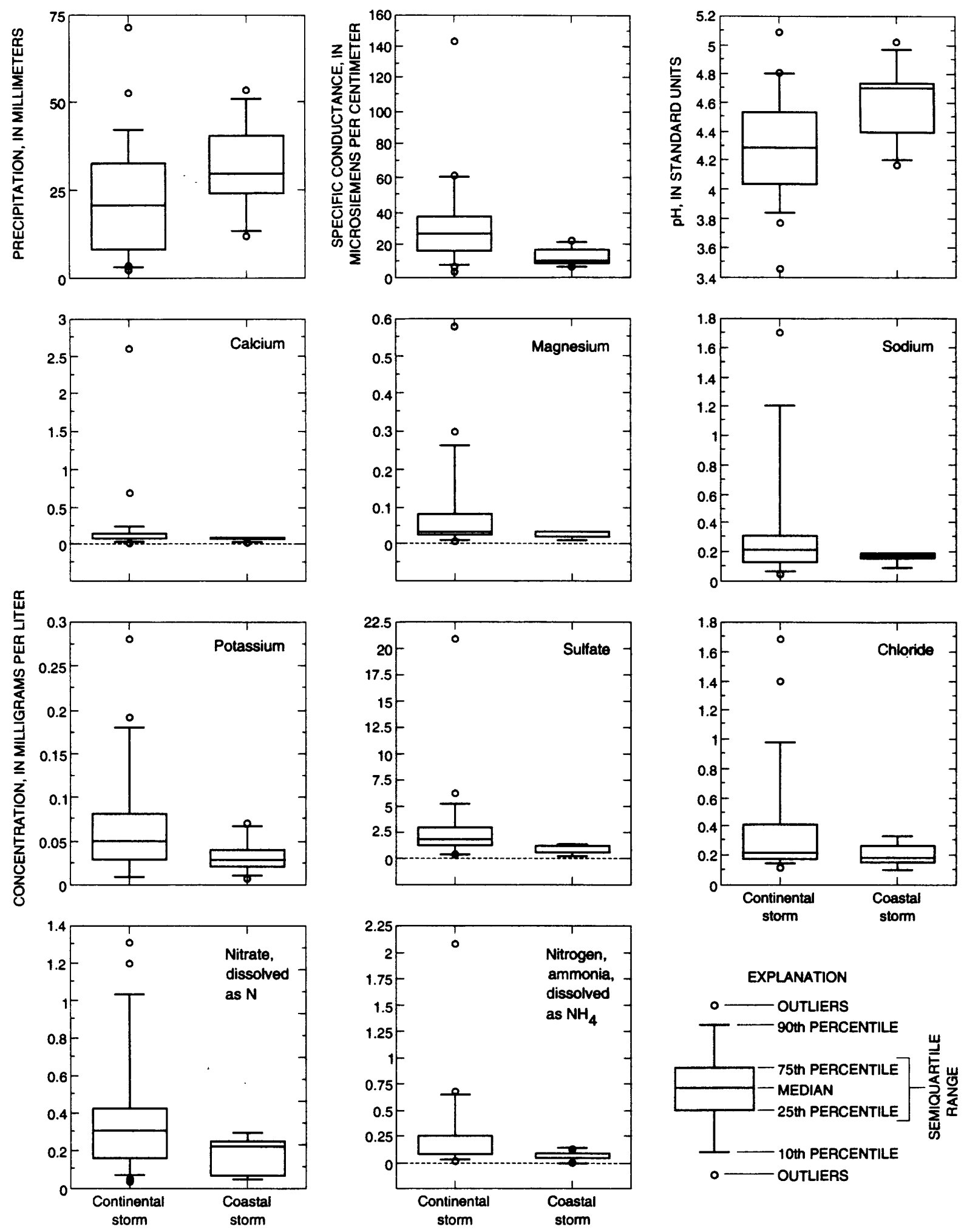

Figure 6. Precipitation depth, specific conductance, and chemical-constituent concentrations from continental and coastal storms, Quabbin Reservoir, central Massachusetts. 

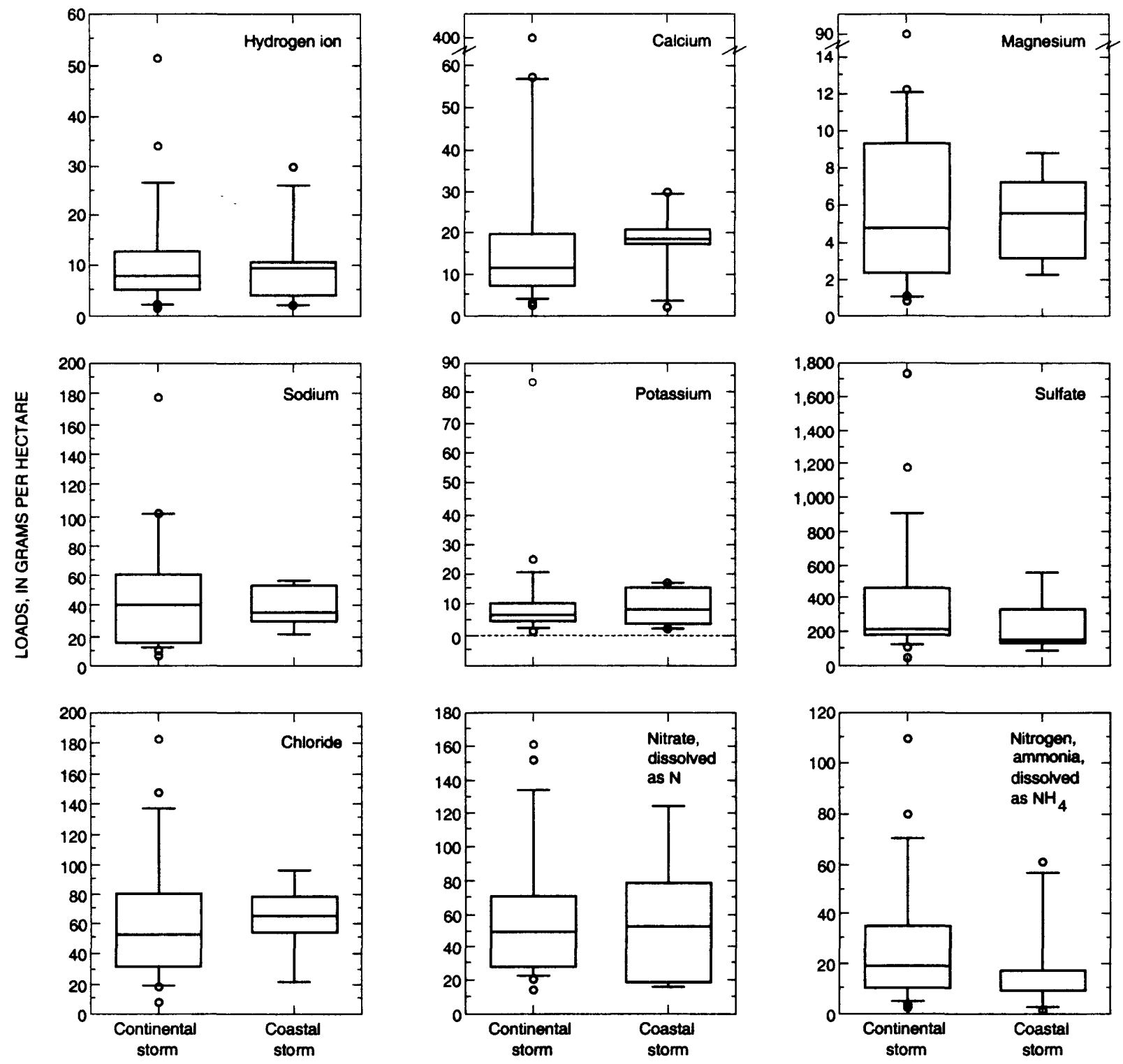

EXPLANATION

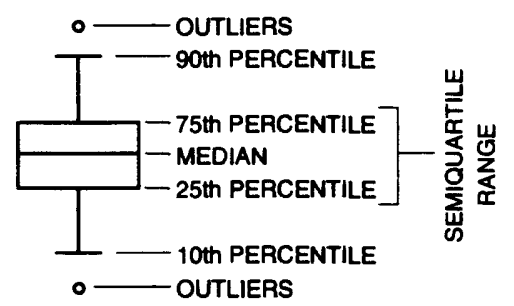

Figure 7. Chemical-constituent loads from continental and coastal storms, Quabbin Reservoir, central Massachusetts. 
Table 3. Classification of 31 storms, Quabbin Resenoir, central Massachusetts, 1986-87

\begin{tabular}{|c|c|c|}
\hline Storm date & $\begin{array}{l}\text { Precipitation } \\
\text { (millimeters) }\end{array}$ & Classification \\
\hline October 13, 1986 & 8.64 & Continental \\
\hline October 26, 1986 & 21.84 & Coastal $^{1}$ \\
\hline November 20, 1986 & 30.48 & Continental \\
\hline November 23, 1986 & 5.08 & Continental \\
\hline November 26, 1986 & 25.15 & Continental \\
\hline December 2, 1986 & 29.46 & Coastal $^{1}$ \\
\hline December 18, 1986 & 52.58 & Continental ${ }^{1}$ \\
\hline December 24, 1986 & 11.68 & Coastal \\
\hline January 1,1987 & 33.02 & Coastal \\
\hline January 10, 1987 & 25.40 & Continental \\
\hline January 18, 1987 & 9.14 & Continental \\
\hline January 22, 1987 & 28.19 & Coastal \\
\hline February 9, 1987 & 4.83 & Continental \\
\hline February 28, 1987 & 33.78 & Continental \\
\hline March 30, 1987 & 71.63 & Continental ${ }^{1}$ \\
\hline April 12, 1987 & 14.73 & Continental $^{2}$ \\
\hline April 17, 1987 & 3.56 & Continental \\
\hline April 24, 1987 & 8.13 & Continental \\
\hline April 28, 1987 & 32.00 & Continental \\
\hline June 22, 1987 & 6.86 & Continental \\
\hline June 26, 1987 & 33.27 & Continental $^{1}$ \\
\hline July 2, 1987 & 16.76 & Continental \\
\hline July 24, 1987 & 3.81 & Continental \\
\hline August 2, 1987 & 40.64 & Continental \\
\hline August 9, 1987 & 36.32 & Continental $^{1,2}$ \\
\hline August 27, 1987 & 29.72 & Continental $^{1}$ \\
\hline September 30, 1987 & 29.97 & Continental $^{2}$ \\
\hline October 3, 1987 & 52.83 & Coastal $^{1}$ \\
\hline November 10, 1987 & 42.93 & Coastal \\
\hline December 12, 1987 & 2.54 & Continental \\
\hline December 15,1987 & 15.49 & Continental \\
\hline
\end{tabular}

${ }^{1}$ Storms used in the variations of within-storm chemistry analyses.

${ }^{2}$ Storms used in the particulate material analyses.
Table 4. Mean, standard deviation, and skewness of precipitation depth, specific conductance, and chemical-constituent concentrations from continental and coastal storms, Quabbin Reservoir, central Massachusetts

[Chemical-constituent concentrations are in milligrams per liter. $\mathrm{mm}$, millimeter; $\mu \mathrm{S} / \mathrm{cm}$, microsiemen per centimeter at 25 degrees Celsius]

\begin{tabular}{|c|c|c|c|c|}
\hline Characteristic & $\begin{array}{l}\text { Number } \\
\text { of samples }\end{array}$ & Mean & $\begin{array}{l}\text { Standard } \\
\text { deviation }\end{array}$ & Skewness \\
\hline \multicolumn{5}{|c|}{ CONTINENTAL STORMS } \\
\hline $\begin{array}{l}\text { Precipitation } \\
\text { depth }(\mathrm{mm})\end{array}$ & 24 & 22.52 & 17.50 & 0.89 \\
\hline $\begin{array}{l}\text { Specific conduc- } \\
\text { tance }(\mu \mathrm{S} / \mathrm{cm})\end{array}$ & 24 & 31.8 & 29.3 & 2.31 \\
\hline Calcium & 24 & .21 & .53 & 3.91 \\
\hline Magnesium & 17 & .09 & .15 & 2.45 \\
\hline Sodium & 21 & .38 & .44 & 1.79 \\
\hline Potassium & 21 & .07 & .07 & 1.52 \\
\hline Sulfate & 22 & 2.93 & 4.31 & 3.31 \\
\hline Chloride & 22 & .4 & .41 & 2.04 \\
\hline Hydrogen & 24 & .075 & .074 & 2.22 \\
\hline $\begin{array}{l}\text { Nitrate, } \\
\text { dissolved as } \mathbf{N}\end{array}$ & 1 & .38 & .35 & 1.44 \\
\hline $\begin{array}{l}\text { Nitrite plus nitrate, } \\
\text { dissolved as } N\end{array}$ & 24 & .43 & .38 & 1.28 \\
\hline $\begin{array}{r}\text { Nitrogen, ammonia } \\
\text { dissolved as } \mathrm{NH}_{4}\end{array}$ & 24 & .25 & .43 & 3.24 \\
\hline
\end{tabular}

\begin{tabular}{|c|c|c|c|c|}
\hline \multicolumn{5}{|c|}{ COASTAL STORMS } \\
\hline $\begin{array}{l}\text { Precipitation } \\
\text { depth }(\mathrm{mm})\end{array}$ & 7 & 31.46 & 13.54 & 0.17 \\
\hline $\begin{array}{l}\text { Specific conduc- } \\
\text { tance }(\mu \mathrm{S} / \mathrm{cm})\end{array}$ & 7 & 12 & 5.74 & .58 \\
\hline Calcium & 6 & .06 & .02 & -.98 \\
\hline Magnesium & 5 & .02 & .01 & -.25 \\
\hline Sodium & 5 & .16 & .04 & -.79 \\
\hline Potassium & 6 & .03 & .02 & .54 \\
\hline Sulfate & 5 & .75 & .46 & .21 \\
\hline Chloride & 5 & .21 & .09 & .28 \\
\hline Hydrogen & 7 & .03 & .02 & .75 \\
\hline $\begin{array}{l}\text { Nitrate, } \\
\text { dissolved as } \mathrm{N}\end{array}$ & 5 & .17 & .11 & -.17 \\
\hline $\begin{array}{l}\text { Nitrite plus nitrate, } \\
\text { dissolved as } \mathrm{N}\end{array}$ & 6 & .17 & .10 & .15 \\
\hline $\begin{array}{r}\text { Nitrogen, ammonia, } \\
\text { dissolved as } \mathrm{NH}_{4}\end{array}$ & 6 & .06 & .05 & .28 \\
\hline
\end{tabular}


Table 5. Mean, standard deviation, and skewness of chemical-constituent loads from continental and coastal storms, Quabbin Reservoir, central Massachusetts

[Chemical-constituent loads are in grams per hectare]

\begin{tabular}{lcrrr}
\hline Characteristic & $\begin{array}{c}\text { Number } \\
\text { of samples }\end{array}$ & Mean & $\begin{array}{c}\text { Standard } \\
\text { deviation }\end{array}$ & $\begin{array}{c}\text { Skew- } \\
\text { ness }\end{array}$ \\
\hline \multicolumn{5}{c}{ CONTINENTAL STORMS } \\
\hline Calcium & 24 & 32.3 & 80.2 & 4.08 \\
Magnesium & 17 & 10.3 & 20.8 & 3.26 \\
Sodium & 21 & 48.4 & 42.2 & 1.41 \\
Potassium & 21 & 11.3 & 17.7 & 3.28 \\
Sulfate & 22 & 413.0 & 402.0 & 1.88 \\
Chloride & 22 & 64.1 & 45.0 & 1.04 \\
Hydrogen & 24 & 11.6 & 11.4 & 2.03 \\
Nitrate, dissolved & 21 & 58.0 & 41.6 & 1.21 \\
$\quad$ as N & & & & \\
$\begin{array}{l}\text { Nitrite plus nitrate, } \\
\text { dissolved as N }\end{array}$ & 24 & 56.9 & 39.9 & 1.37 \\
$\begin{array}{c}\text { Nitrogen, ammonia, } \\
\text { dissolved as NH }\end{array}$ \\
\hline
\end{tabular}

COASTAL STORMS

\begin{tabular}{|c|c|c|c|c|}
\hline Calcium & 6 & 17.8 & 8.96 & -0.45 \\
\hline Magnesium & 5 & 5.32 & 2.6 & .0965 \\
\hline Sodium & 5 & 39.0 & 15.2 & .0714 \\
\hline Potassium & 6 & 9.27 & 6.32 & .074 \\
\hline Sulfate & 5 & 239.4 & 189.1 & .804 \\
\hline Chloride & 5 & 63.8 & 26.7 & -.42 \\
\hline Hydrogen & 7 & 10.1 & 9.29 & 1.19 \\
\hline $\begin{array}{l}\text { Nitrate, dissolved } \\
\text { as } \mathrm{N}\end{array}$ & 5 & 54.6 & 44.0 & .55 \\
\hline $\begin{array}{l}\text { Nitrite plus nitrate, } \\
\text { dissolved as } \mathrm{N}\end{array}$ & 6 & 49.7 & 45.1 & .89 \\
\hline $\begin{array}{l}\text { Nitrogen, ammonia, } \\
\text { dissolved as } \mathrm{NH}_{4}\end{array}$ & 6 & 17.9 & 21.3 & 1.19 \\
\hline
\end{tabular}

In the Mann-Whitney test, all samples from both groups having size $n_{1}$ and $n_{2}$ are combined into one group. Starting with the smallest, each value is then ranked 1 through $n_{1}+n_{2}$. The test statistic is computed by the relation

$$
U=n_{1} n_{2}+\left[\left(n_{1}\left(n_{1}+1\right)\right) / 2\right]-R_{1},
$$

where

$U$ is the test statistic,

$n_{1}$ is the number of samples in the first group,

$n_{2}$ is the number of samples in the second group, and
$R_{1} \quad$ is the sum of the ranked samples of the first group.

A $Z$ value is computed by standardizing the $U$ value. This is shown by the relation

$$
Z=[U-M] / S D,
$$

where

$Z$ is the standard normal form value,

$M$ is the mean of the ranked samples in the combined group, and

$S D$ is the standard deviation of the ranked samples in the combined group.

The mean is computed by the relation

$$
M=n_{1} n_{2} / 2 .
$$

The standard deviation is computed by the relation

$$
S D=\sqrt{\frac{n_{1} n_{2}\left(n_{1}+n_{2}+1\right)}{12}} .
$$

At the 5-percent level of significance, the null hypothesis, which states that the means of the two groups are equal, should be rejected if the $Z$ value is less than -1.96 or greater than 1.96 . These values are taken from a normal distribution table for a two-tailed test. $Z$ values for physical and chemical characteristics for concentration and load for the two storm groups were computed (tables 6-7). The means of specific conductance and the concentrations of sulfate are significantly different between the two groups (table 6). None of the means for loads of the chemical constituents were significantly different (table 7).

An alternative hypothesis that the mean of a continental storm characteristic is significantly greater than the mean of a coastal storm characteristic, can be rejected at the 5-percent level if the $Z$ value is less than -1.64 . The means of specific conductance, hydrogen, nitrite-plus-nitrate, and sulfate on a concentration basis for continental storms were significantly greater than the means of these characteristics for coastal storms (table 6). On a load basis, mean values for any characteristics of one storm group were not greater than the mean values of the other storm group (table 7).

The limited number of storms used in this analysis precludes definitive conclusions. Based on the ionic concentration of precipitation, continental storms are more acidic than coastal storms (table 6); however, the total load of acids deposited during a storm for both storm groups is not significantly different. This similarity of total loads is explained by the higher mean 
Table 6. Results of Mann-Whitney nonparametric test of equivalent means of precipitation depth, specific conductance, and chemical-constituent concentrations for continental and coastal storms, Quabbin Reservoir, central Massachusetts

[ $Z$ value, computed test statistic; $p$ value, computed decimal percent level of significance]

\begin{tabular}{lcc}
\hline Characteristic & $Z$ value & $p$ value \\
\hline Precipitation depth & -1.32 & 0.186 \\
Specific conductance & -2.29 & 12.0218 \\
Calcium & -.86 & .39 \\
Magnesium & -1.5 & .135 \\
Sodium & -1.17 & .24 \\
Potassium & -1.35 & .178 \\
Sulfate & -2.15 & 12.0312 \\
Chloride & -1.16 & .248 \\
Hydrogen & -1.82 & 2.0688 \\
Nitrate, dissolved as $\mathrm{N}$ & -1.37 & .172 \\
Nitrite plus nitrate, & -1.81 & 2.0695 \\
$\quad$ dissolved as N & & .133 \\
Nitrogen, ammonia, & -1.5 & \\
dissolved as $\mathrm{NH}_{4}$ & & \\
\hline
\end{tabular}

${ }^{1}$ Mean values of the two storm-path groups are not equal at the 5-percent significance level $(Z= \pm 1.96)$ for this characteristic.

2 The mean of the continental storm characteristic is greater than the mean of the coastal storm characteristic at the 5-percent level of significance $(Z=-1.64)$.

Table 7. Results of Mann-Whitney nonparametric test of equivalent means of chemical-constituent loads for continental and coastal storms, Quabbin Reservoir, central Massachusetts

[ $Z$ value, computed test statistic; $p$ value, computed decimal percent level of significance. The characteristics do not exceed the $Z$ values of \pm 1.96 and -1.64 required to reject the two null hypotheses at the 5-percent level of significance]

\begin{tabular}{lrr}
\hline Characteristic & $Z$ value & $p$ value \\
\hline Calcium & -0.83 & 0.407 \\
Magnesium & -.08 & .938 \\
Sodium & -.03 & .974 \\
Potassium & -.35 & .726 \\
Sulfate & -1.12 & .261 \\
Chloride & -.59 & .553 \\
Hydrogen & -.28 & .777 \\
Nitrate, dissolved as $\mathrm{N}$ & -.73 & .468 \\
Nitrite plus nitrate, & -.42 & .672 \\
$\quad$ dissolved as $\mathrm{N}$ & & .233 \\
Nitrogen, ammonia, & -1.19 & \\
\multicolumn{1}{c}{ dissolved as $\mathrm{NH}_{4}$} & & \\
\hline
\end{tabular}

precipitation depth of coastal storms compared with that of continental storms. These results do not provide information regarding the temporal distribution of the acid deposition during a given storm. By examining the temporal distribution of acid deposition, which is explored in the following section, one can estimate what proportion of acids are derived from washout as opposed to rainout. If most of the acids in the continental storm group are the result of rainout, these acids theoretically could be from sources west of Massachusetts.

\section{VARIATIONS OF WITHIN-STORM CHEMISTRY DURING SELECTED STORMS}

The second objective of the study was to relate changes in the chemical-constituent concentrations in incremental precipitation samples to meteorological characteristics (precipitation intensity, temperature, dewpoint, wind speed, and wind direction) and ambient air quality (nitrogen and sulfur dioxide concentrations).

\section{Use of pH and Specific Conductance as Indicators of Chemical Changes}

The volume of most of the incremental precipitation samples from the 31 storms were insufficient for complete chemical analysis. When possible, however, $\mathrm{pH}$ and specific conductance were measured. A complete suite of hourly or almost hourly measurements of $\mathrm{pH}$ and specific conductance was obtained for 8 of the 31 storms. An analysis was done to determine whether $\mathrm{pH}$ or specific conductance could be used as an adequate surrogate for any of the other chemical constituents in the samples. Data from the 31 storms were used to correlate $\mathrm{pH}$ and specific conductance from the composite samples with individual chemical constituent concentrations (table 8). Data were log transformed before computing the correlations to compensate for skewed data distribution. (Transformations were not done for $\mathrm{pH}$, which is by definition log-transformed.)

The correlation coefficient between specific conductance and all other constituents was slightly larger than the coefficient between $\mathrm{pH}$ and other constituents. $\mathrm{pH}$ and log-transformed specific conductance are highly cross-correlated ( $r=-0.98$, fig. 8 ). In general, specific conductance is an excellent predictor of sulfate and nitrate, a good predictor of ammonium, and a fair predictor of base cations and chloride. The correlation of log-sulfate concentration with log-specific conductance 
Table 8. Comparison of $\mathrm{pH}$ and specific conductance as surrogates of solute con-centrations in 31 composite storm samples from Quabbin Reservoir, central Massachusetts

[Specific conductance and solute concentrations were log transformed; --, no data]

\begin{tabular}{lcc}
\hline & \multicolumn{2}{c}{ Correlation coefficient } \\
\cline { 2 - 3 } \multicolumn{1}{c}{$\begin{array}{c}\text { Properties and } \\
\text { constituents }\end{array}$} & $\begin{array}{c}\text { pH used as } \\
\text { surrogate }\end{array}$ & $\begin{array}{c}\text { Specific } \\
\text { conductance } \\
\text { used as } \\
\text { surrogate }\end{array}$ \\
\hline Specific conductance & -0.98 & -- \\
pH & -- & -0.98 \\
Calcium, dissolved & -.29 & .37 \\
Magnesium, dissolved & -.36 & .42 \\
Sodium, dissolved & -.57 & .60 \\
Potassium, dissolved & -.54 & .55 \\
Sulfate, dissolved & -.96 & .98 \\
Chloride, dissolved & -.32 & .43 \\
Nitrate, dissolved, as N & -.93 & .95 \\
Nitrite plus nitrate, & -.93 & .94 \\
dissolved as N & & .85 \\
Nitrogen, ammonia, & -.82 & \\
dissolved as N & & \\
\hline
\end{tabular}

was particularly noteworthy ( $r=0.98$, fig. 9). Changes in specific conductance during a storm can thus be used with confidence to estimate changes in sulfate concentrations.

The results of the correlations are an indication of the dominant control that strong acids have on precipitation chemistry. Because of the high specific conductance of hydrogen ions, they have an effect on the specific conductance of precipitation that is disproportionately high relative to the contribution of hydrogen ions to the total ionic composition. Except in very dilute precipitation samples, hydrogen ion is the dominant cation, and sulfate and nitrate are the dominant anions (Drever, 1988). Thus, variations in these three species directly affect specific conductance. In contrast, the concentrations of base cations and chloride are too low to significantly affect specific conductance. The insignificant effect indicates that concentrations of base cations and chloride do not increase or decrease with those of the acidic species, as would result from concentration by evaporation or from simple dilution. The insignificant effect may indicate that the sources of acidic species in precipitation differ from those of base cations.

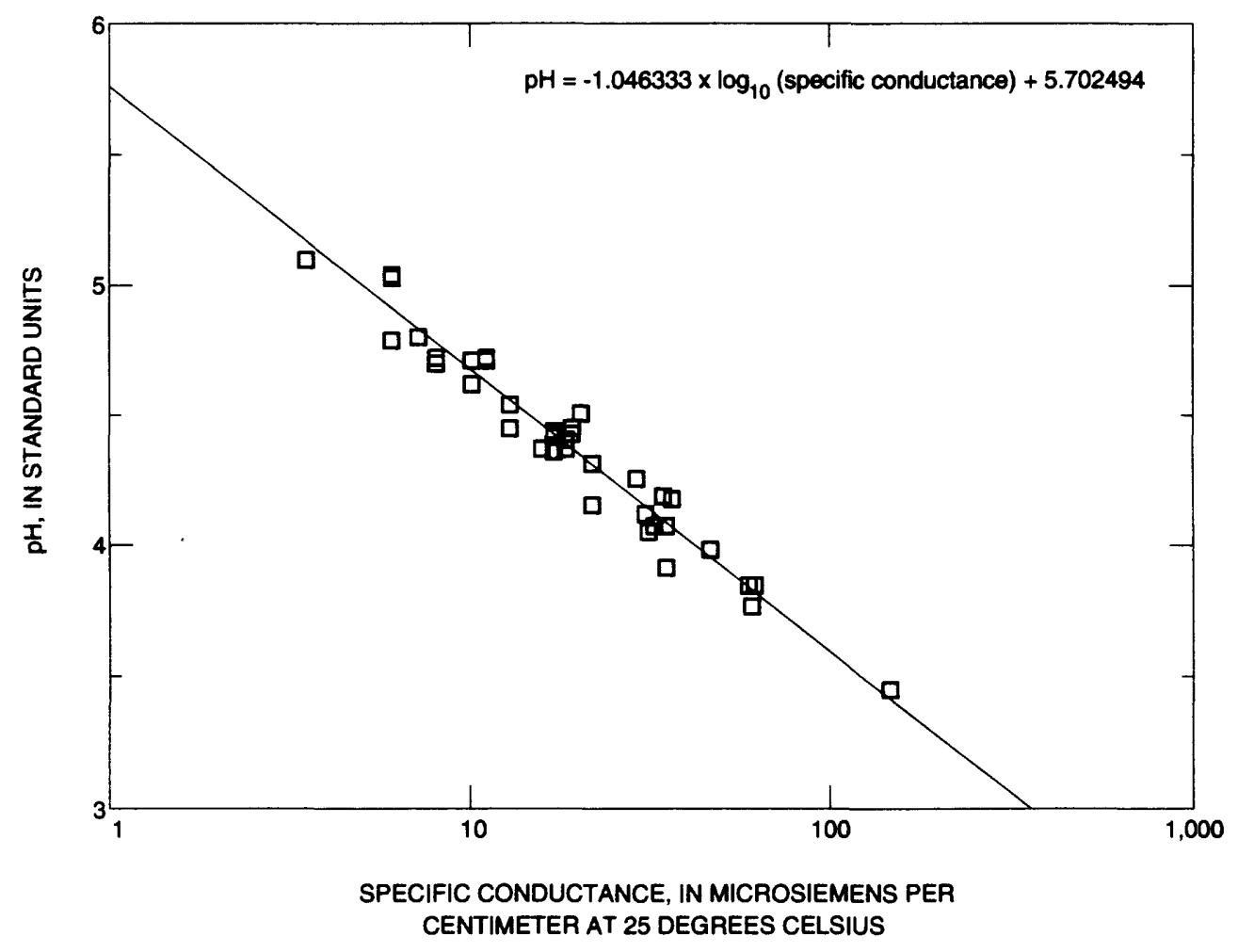

Figure 8. Relation between log-transformed specific conductance and $\mathrm{pH}$ in composite storm samples, Quabbin Reservoir, central Massachusetts. 


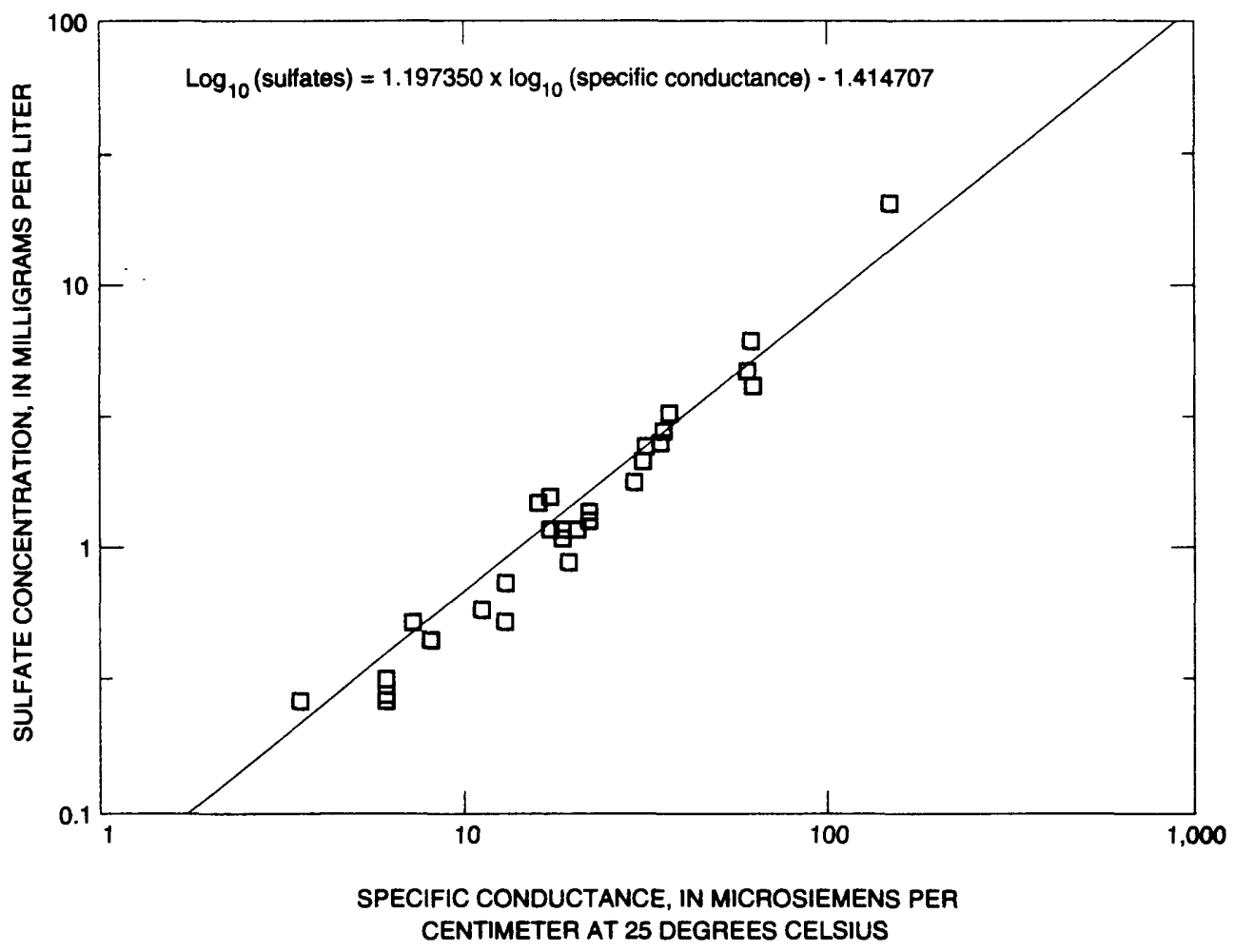

Figure 9. Relation between log-transformed specific conductance and sulfate in composite storm samples, Quabbin Reservoir, central Massachusetts.

A second set of correlations was done on subsets of the data divided into samples from the coastal storms and samples from the continental storms. Hypothetically, specific conductance would be a better predictor of base cations and chloride in the coastal storm group than in the continental storm group due to the presence of salt in oceanic aerosols. However, the correlation coefficients were not significantly improved.

\section{Interactions Between Preciplitation Intensity and Hydrogen-lon Loading}

Cumulative precipitation depth and cumulative hydrogen-ion loads during eight storms are shown in figure 10. Five of the storms had a continental path and the remaining three storms had a coastal path. Presentation of hydrogen ion as a cumulative load illustrates the temporal distribution of hydrogen-ion deposition during the storm. The rate of deposition of acid in relation to storm intensity can be inferred from the slope of the line.

Cumulative precipitation and cumulative hydrogen-ion load are shown in figure 10. By removing time as a variable, the rates of cumulation of precipitation and hydrogen ions can be easily compared. The data indicate the proportion of acids deposited in a storm that may be the result of washout as opposed to rainout. Washout, defined as accumulated locally derived material removed from the air column beneath the storm clouds and not replenished during a storm would be expected to occur during the early part of a storm (Junge, 1963). A convex curve in these graphs would be evidence of washout in the early phase of the storms. Rainout represents long-range transported material that is continually supplied throughout the storm. Evidence of rainout would usually be a straightline curve.

Evidence of washout can be seen in all of the storms except for the storm beginning on August 9, 1987 (fig. 10). The storm beginning on October 26, 1986 (fig. 10) has a pronounced pattern of washout. About 40 percent of the hydrogen-ion load was deposited during the first 10 percent of rainfall. The storm of August 9 shows a very even distribution of rainout acid deposition throughout the duration of the storm. Most of these acids may have been transported into the region with the incoming air mass. The storm was characterized as continental. The composite sample 

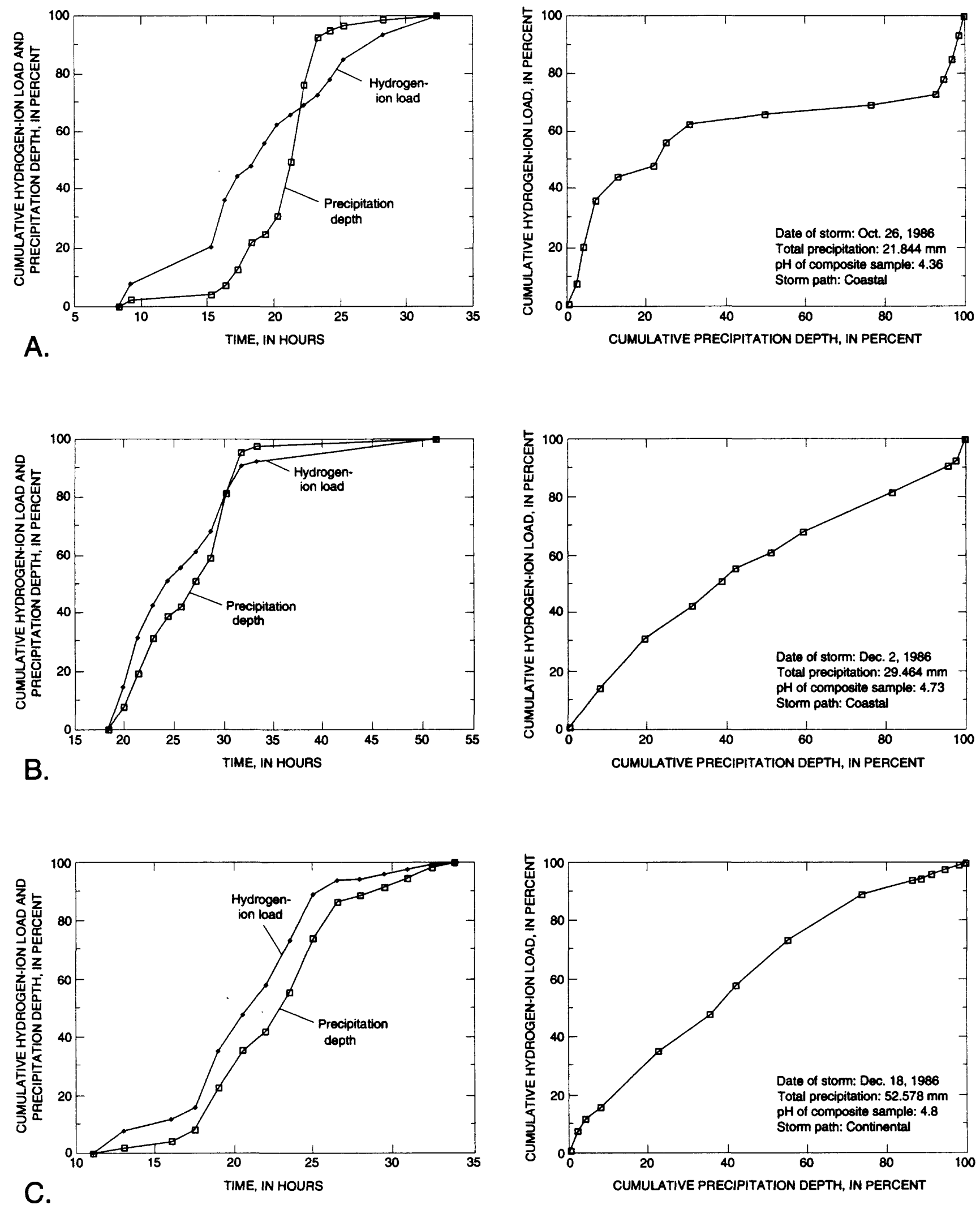

Figure 10. Relations between cumulative precipitation depth and cumulative hydrogen-ion loads with time and with each other for selected storms, Quabbin Reservoir, central Massachusetts. A, October 2627, 1986. B. December 2-3, 1986. C, December 18-19, 1986. D. March 30-April 1, 1987. E, June 26-27. 1987. F, August 9-10, 1987. G, August 27-29, 1987, H, October 3-4, 1987. 

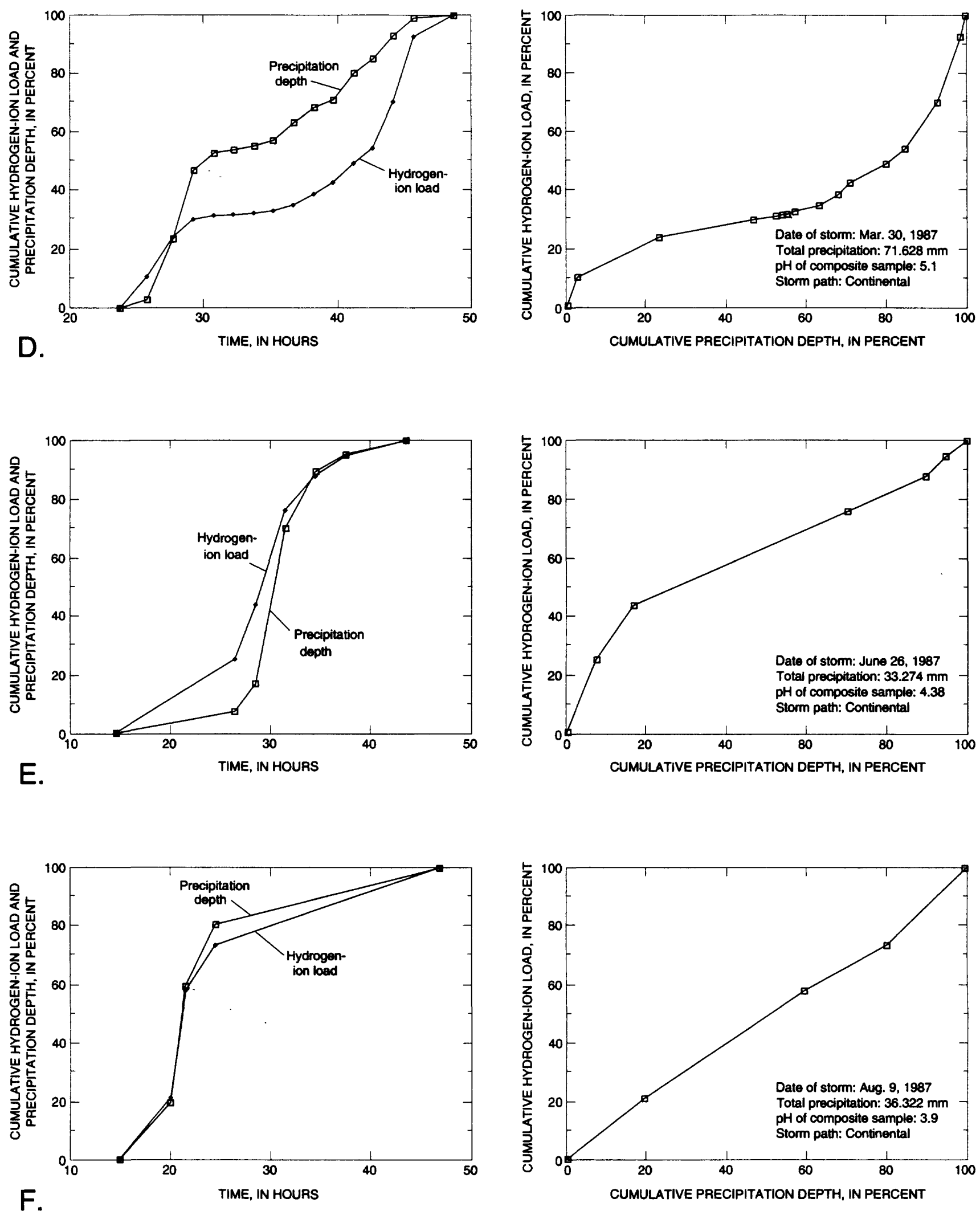

Figure 10.--Continued. 

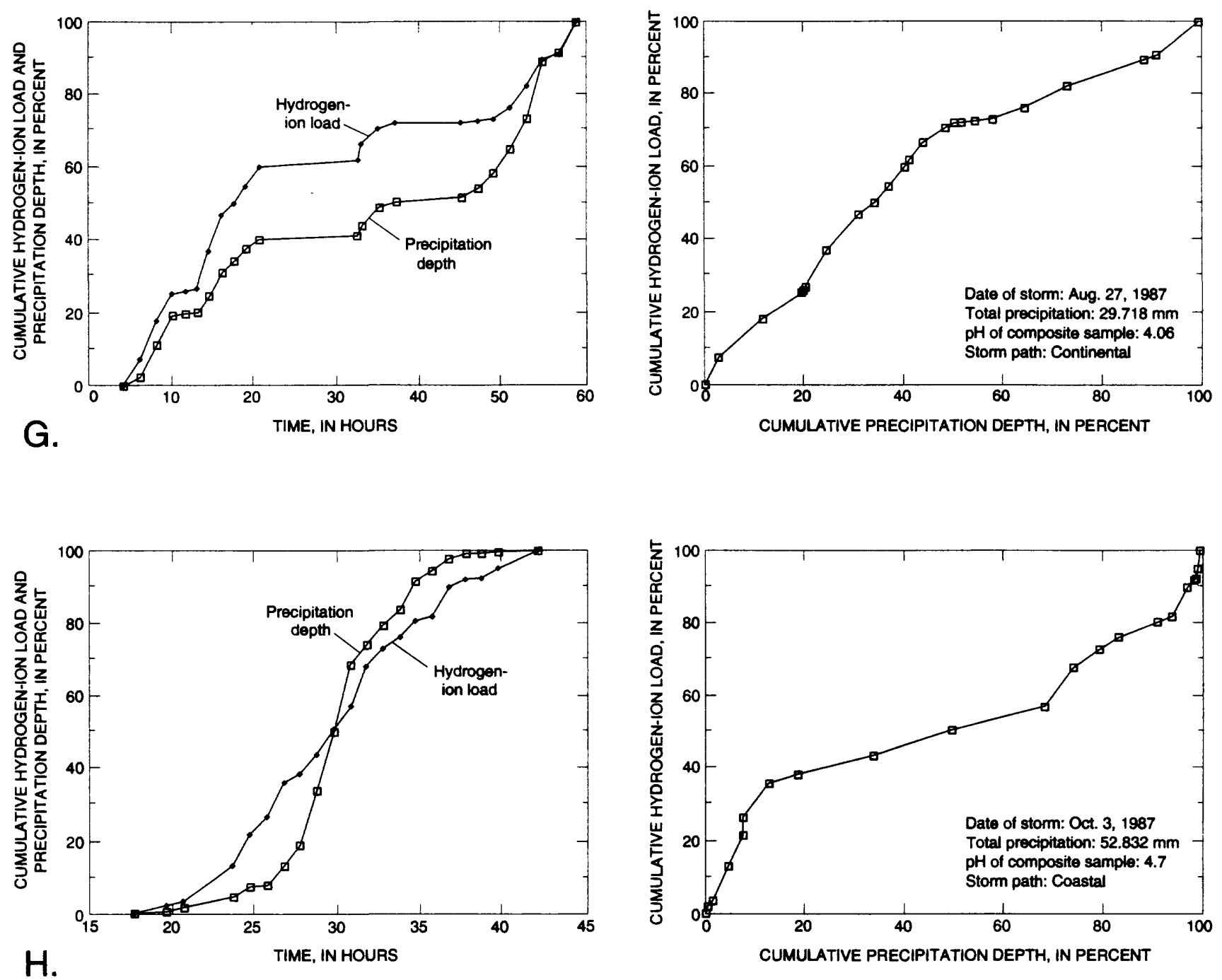

Figure 10.--Continued.

of the storm also was the most acidic with a pH of 3.9 . These two storms and the storm beginning on March 30, 1987 , are discussed in detail in the "Selected Storms" section. Some of the storms showed increased hydrogen-ion loading in the final hours of the storm. The increased loading as the storm intensity decreases is an indication of less dilution and increased evaporation. Because this is occurring in the final phase of the storm, this is more likely an indication of a rainout process as opposed to a washout process.

Categorically, defining characteristics of storms contributing to acid deposition by storm path and storm type is difficult on the basis of only eight storms. Determining the origins of atmospheric moisture and chemical constituents requires analysis of many variables. A minimum of two air masses is associated with any storm. Distinct patterns rarely emerge in precipitation chemistry. By analysis of the meteorology of these eight storms, however, some speculation can be made regarding its effect on acidic deposition.

\section{Interactions Between Precipitation Intensity, Field pH, and Air Quality}

The air-quality data (table 1) collected at the site were used in conjunction with the acid-deposition data collected in this study to interpret changes in air quality before, during, and after selected storms. A decrease in sulfur dioxide, nitrogen dioxide, and suspended particulates in the atmosphere at land surface during the storm was assumed to be evidence of washout. Precipitation 
Table 9. Results of particulate materials analysis for three continental storms, Quabbin Reservoir, central Massachusetts

$\left[\mu \mathrm{m}\right.$, micrometer; $\mathrm{cm}^{2}$, square centimeter]

\begin{tabular}{|c|c|c|c|}
\hline Date and time & $\begin{array}{c}\text { Minerals } \\
\text { present }\end{array}$ & $\begin{array}{l}\text { Size } \\
\text { range } \\
(\mu \mathrm{m})\end{array}$ & $\begin{array}{c}\text { Density } \\
\left(10^{3} \text { particles } /\right. \\
\left.\mathrm{cm}^{2}\right)\end{array}$ \\
\hline \multirow{3}{*}{$\begin{array}{l}\text { Apr. 12-13, } 1987 \\
\text { (composite) }\end{array}$} & Biotite & $1-30$ & 160 \\
\hline & Ilmenite & $5-7$ & 10 \\
\hline & Quartz & $5-7$ & 40 \\
\hline \multirow{6}{*}{$\begin{array}{l}\text { Aug. 9-11, } 1987 \\
\text { (composite) }\end{array}$} & Biotite & $4-6$ & 5 \\
\hline & Garnet & 4-6 & 5 \\
\hline & Gypsum & $3-10$ & 125 \\
\hline & Halite & $2-5$ & 10 \\
\hline & Hematite & $1-3$ & 10 \\
\hline & Quartz & $1-3$ & 10 \\
\hline Aug. $9(2120)$ to & Garnet & $0.5-3$ & 286 \\
\hline $\begin{array}{l}\text { Aug. } 10(0020) \text {, } \\
1987 \text { (incremental) }\end{array}$ & Quartz & $0.5-3$ & 228 \\
\hline Aug. $10(0020)$ to & Biotite & $4-6$ & 6 \\
\hline Aug. $11(0800)$, & Eggonite & $0.5-1.5$ & 9 \\
\hline \multirow[t]{6}{*}{1987 (incremental) } & Epidote & $4-6$ & 14 \\
\hline & Garnet & $0.2-2$ & 66 \\
\hline & Hematite & $1-3$ & 20 \\
\hline & Ilmenite & $0.2-1$ & 9 \\
\hline & $\begin{array}{l}\text { Organic ash } \\
\quad+\mathrm{K}_{2} \mathrm{O}\end{array}$ & $0.3-0.8$ & 6 \\
\hline & Quartz & $2-4$ & 33 \\
\hline \multirow{5}{*}{$\begin{array}{l}\text { Sept. 30, } 1987 \\
\text { (composite) }\end{array}$} & Biotite & $0.5-1.5$ & 50 \\
\hline & Garnet & $1-2$ & 10 \\
\hline & Halite & $1-4$ & 30 \\
\hline & Quartz & $3-5$ & 20 \\
\hline & Rutile & $1-2$ & 10 \\
\hline
\end{tabular}

depth, surface air temperature and dewpoint, surfaceatmospheric sulfur dioxide, nitrogen dioxide, and $\mathrm{pH}$ for selected storms are listed in figure 11. Precipitation $\mathrm{pH}$ for the eight storms is listed in figure 10.

With the exception of the storm of October 3-4, 1987 (fig. $11 \mathrm{H}$ ), concentrations of sulfur dioxide and nitrogen dioxide in the air decreased somewhat when the storm began. Sulfur dioxide and nitrogen dioxide concentrations increased after all the storms ended. Concentrations of sulfur dioxide and nitrogen dioxide in the air were greater after the storm than before the storm for three storms: March 30-April 1, 1987 (fig. 11D), August 9-10, 1987 (fig. 11F), and October 3-4, 1987 (fig. $11 \mathrm{H}$ ). Surface-air temperature and dewpoint data for these storms show evidence of a new, cooler air mass replacing the pre-storm air mass. Thus, although precipitation is commonly thought to cleanse the atmosphere, the effect may be short-lived as a new, sometimes more contaminated air mass moves into the region.

\section{Particulate Material}

Five filter membranes from composite and incremental samples for three storms were analyzed for particulate materials (table 9). Although the three storms were classified as continental, the mineralogy of the individual samples was diverse. Of the five samples, two were dominated by biotite, two by garnet, and one by gypsum. Each sample contained various amounts of accessory minerals, the most common of which was quartz (present in all samples). Other minerals identified were eggonite, epidote, halite, hematite, ilmenite, organic ash, and rutile. Although the particle-size distribution ranged well over an order of magnitude, the particle-size range of each mineral in a given sample was relatively narrow. This characteristic size range for a given mineral generally was maintained among all samples, except for biotite, which ranged considerably in size from sample to sample.

The large sizes of particles would indicate that the minerals identified in the analysis were of local origindust from dirt roads, agriculture, or construction. The $0.4-\mu \mathrm{m}$ pore size of the filter membranes captures particles that generally are too large to be useful indicators of long-range transport. Particles greater than $0.4 \mu \mathrm{m}$ in size are unlikely to be transported long distances (Richard Poirot, Vermont Division of Air Quality, oral commun., 1991.)

Mineralogically, particulate materials from the April and September storms were similar, except that the particle sizes for the April storm were considerably larger. The larger particle sizes of the April storm may have resulted from higher surface wind speeds at that time. Hourly wind-speed data for the April storm ranged from 15 to $30 \mathrm{~km} / \mathrm{h}$. Wind speed during the September storm was less than $15 \mathrm{~km} / \mathrm{h}$. 

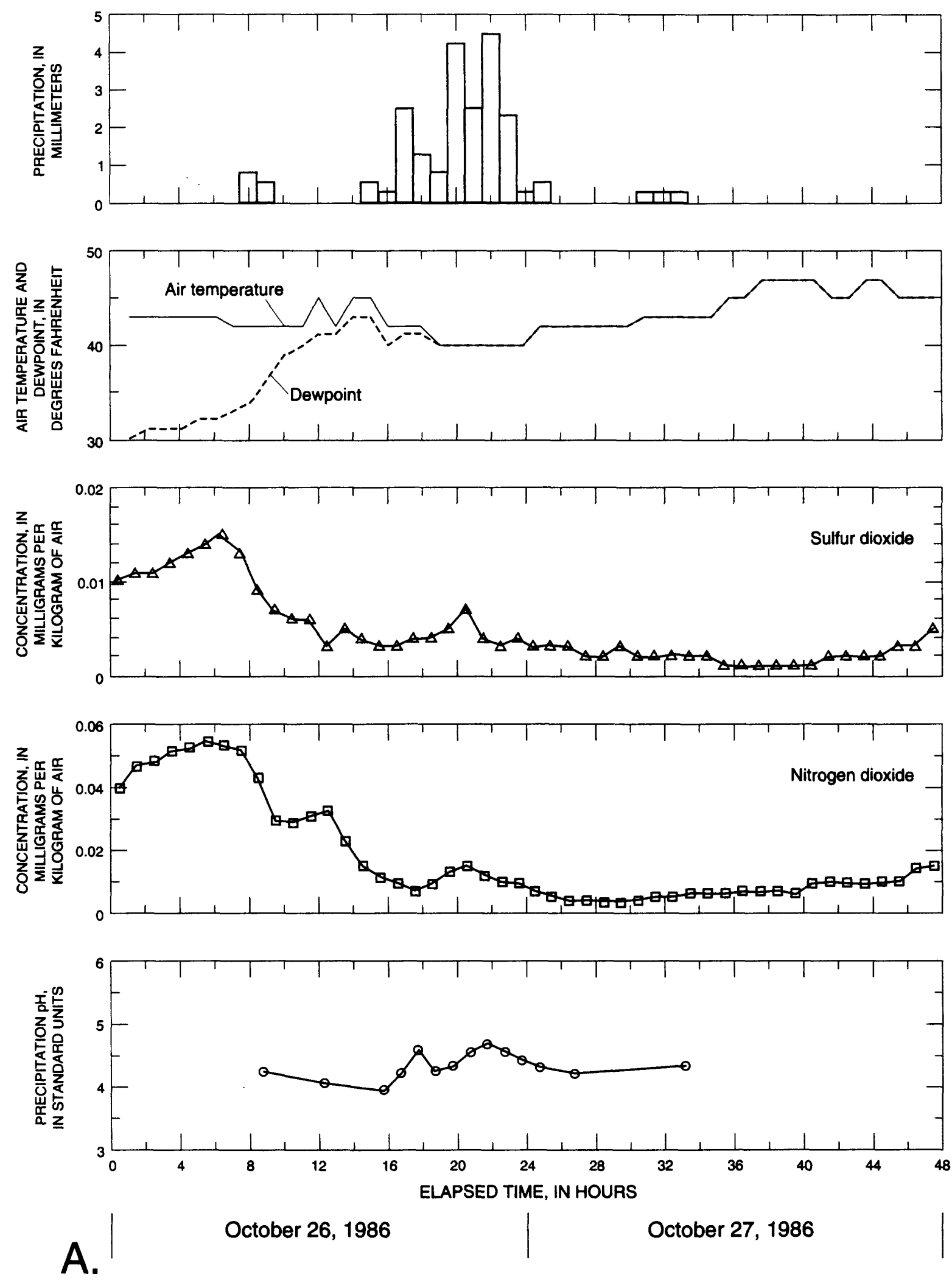

Figure 11. Precipitation, surface-air temperature and dewpoint, surface-atmospheric sulfur dioxide and nitrogen dioxide, and $\mathrm{pH}$ for selected storms, Quabbin Reservoir, central Massachusetts. A, October 26-27, 1986. B, December 2-3, 1986. C, December 18-19, 1986. D. March 30-April 1, 1987. E, June 26-27, 1987. F, August 9-10, 1987. G. August 27-29, 1987, H, October 3-4, 1987. 

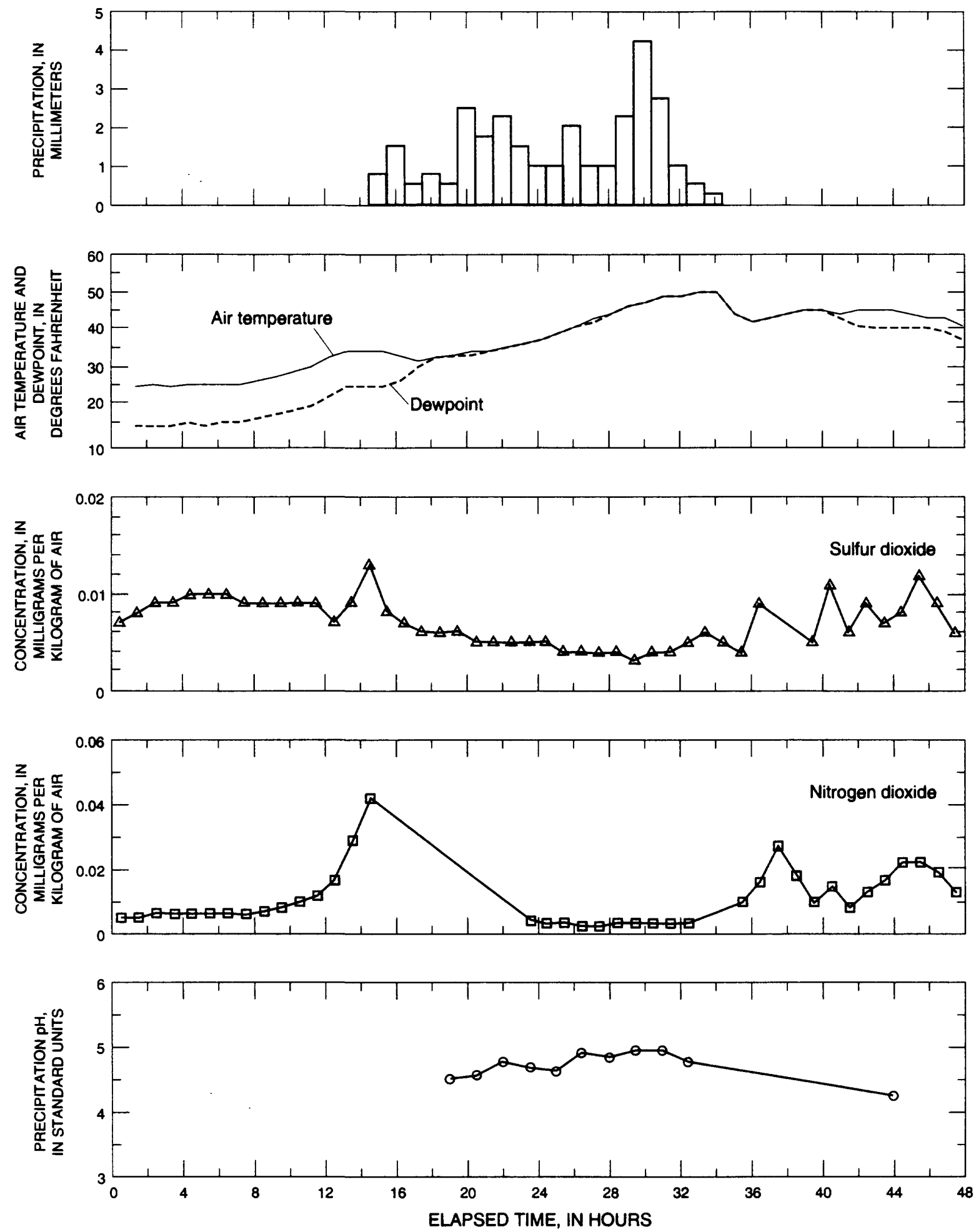

B. December 2, $1986 \quad$ December 3, 1986

Figure 11.--Continued 

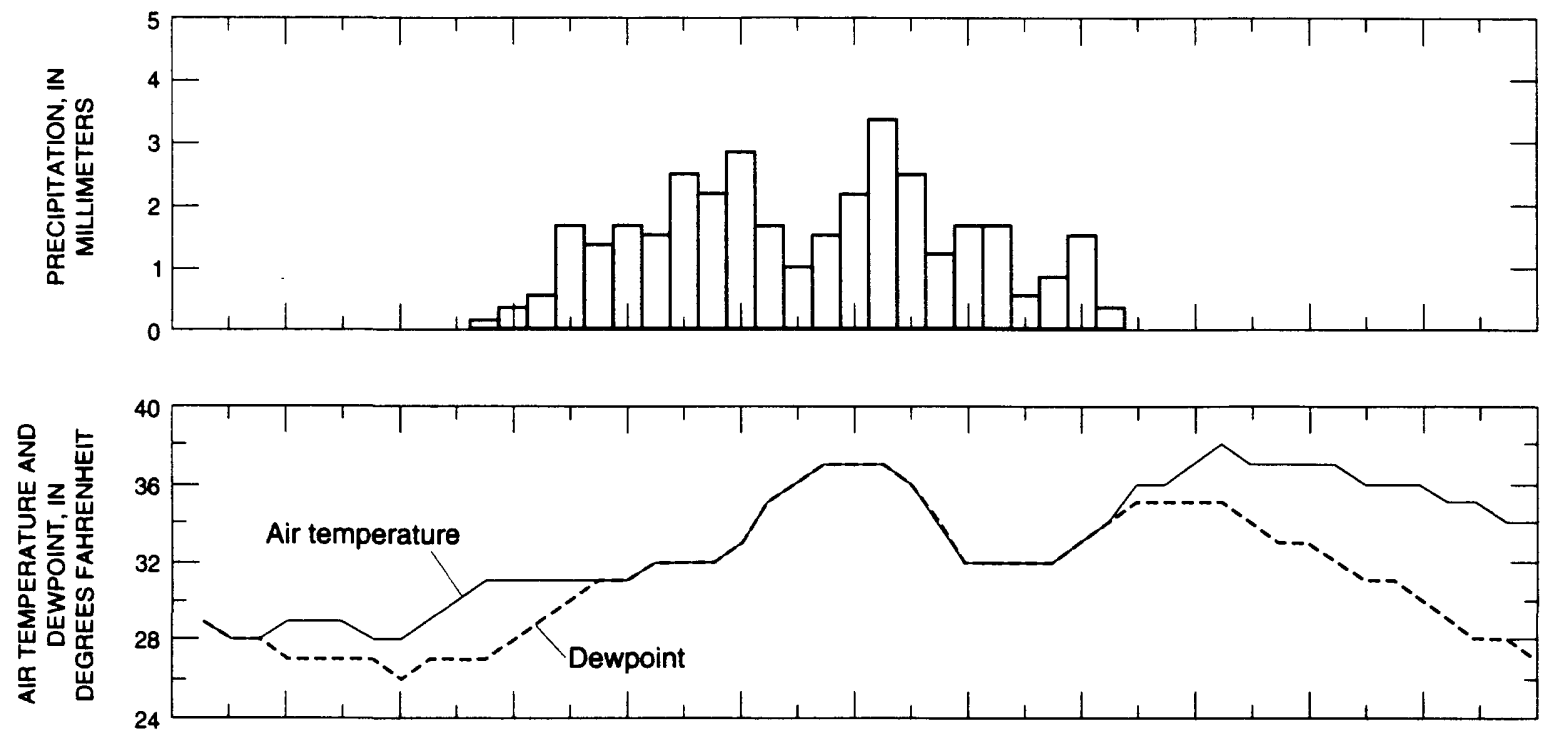

No sulfur dioxide data for this storm
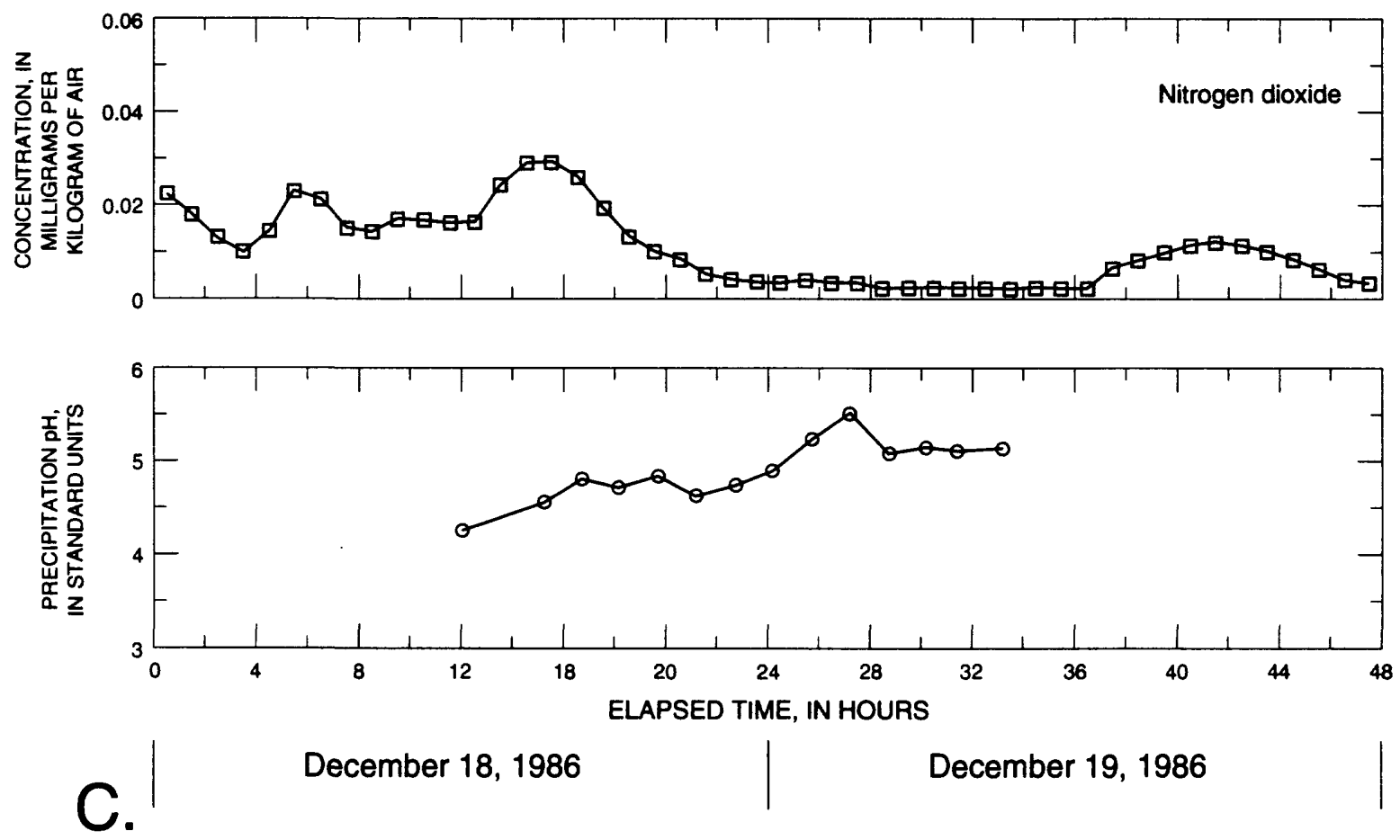

Figure 11.--Continued 

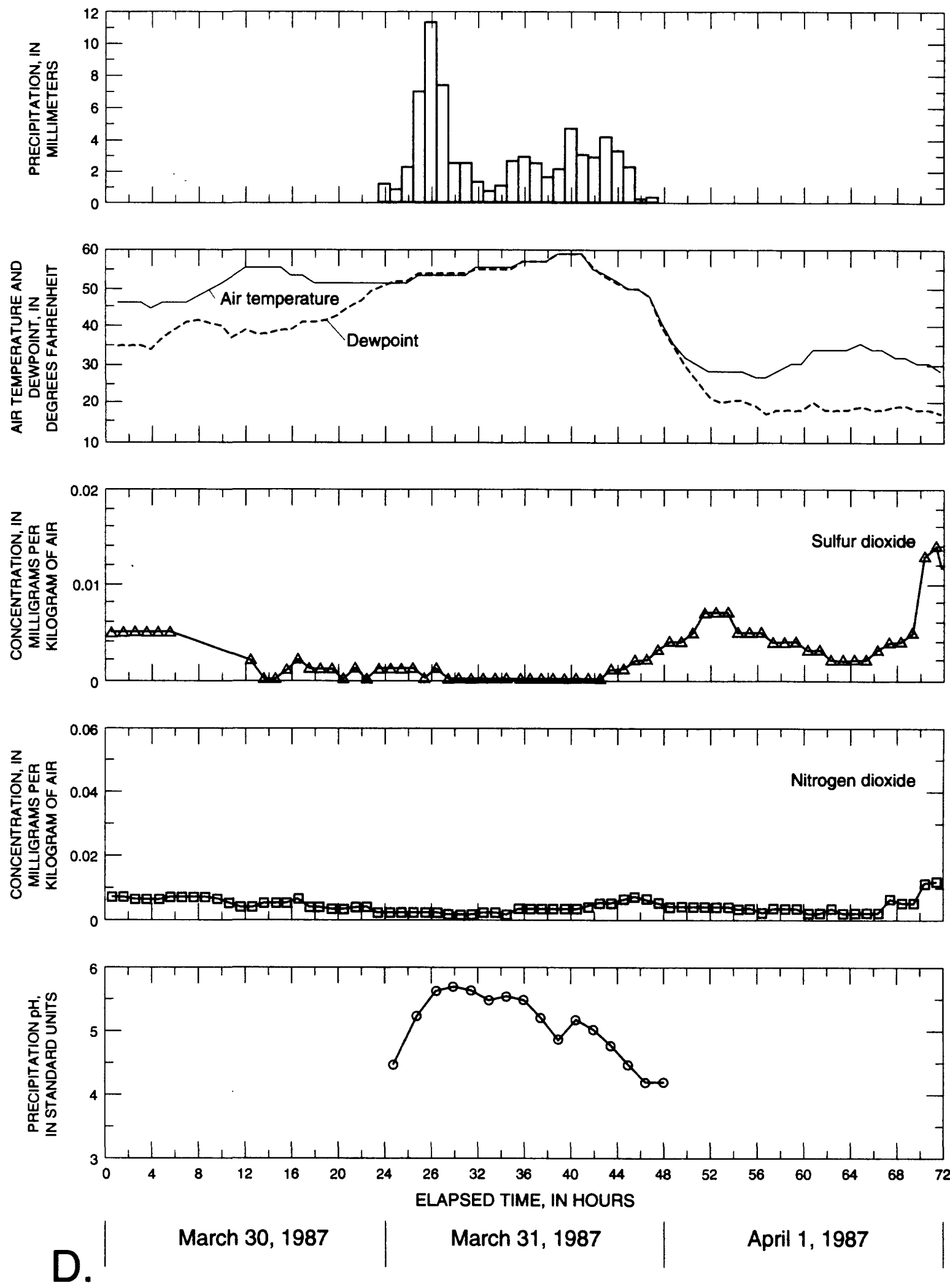

Figure 11.--Continued 

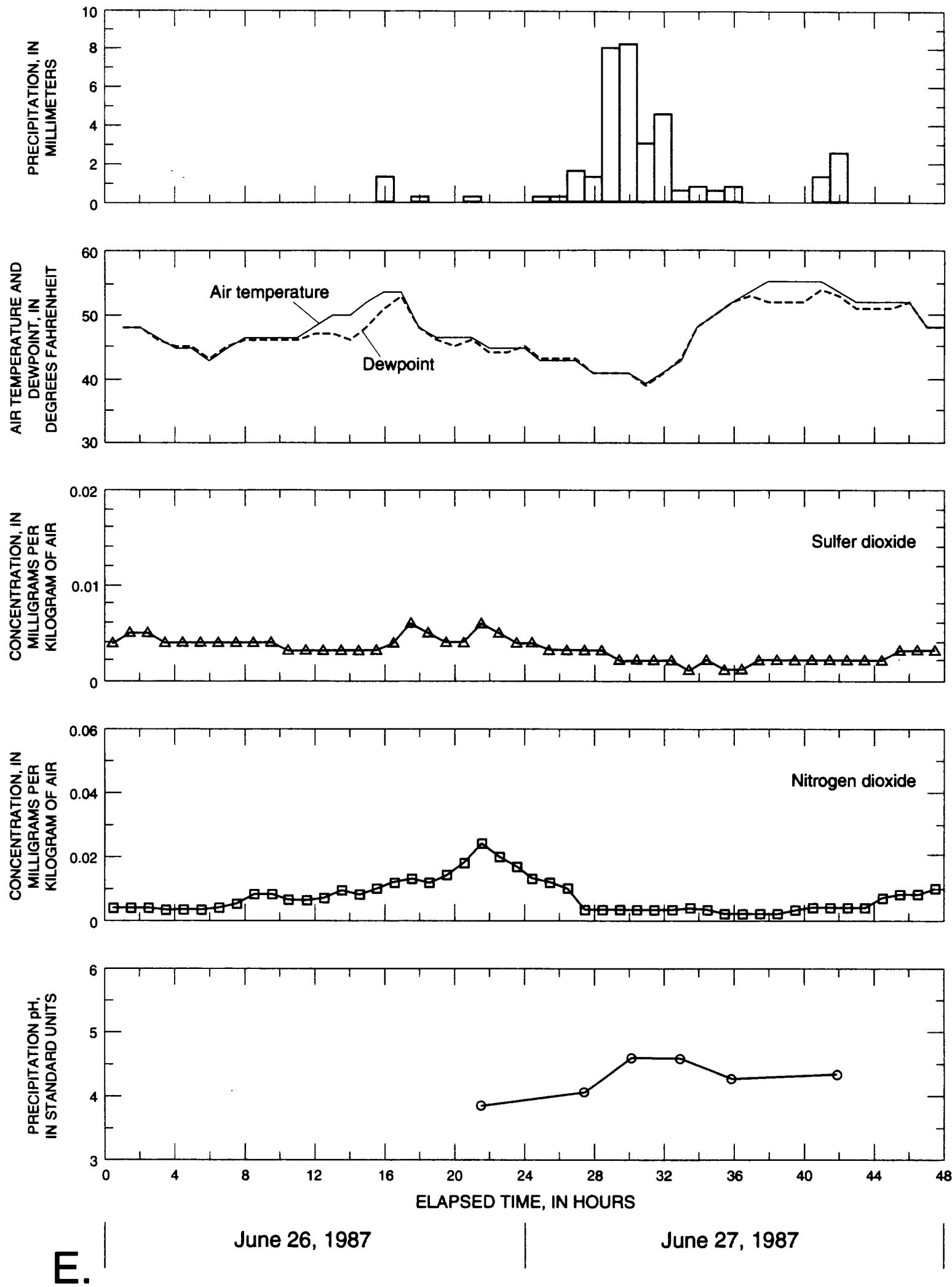

June 27, 1987

Figure 11.--Continued 

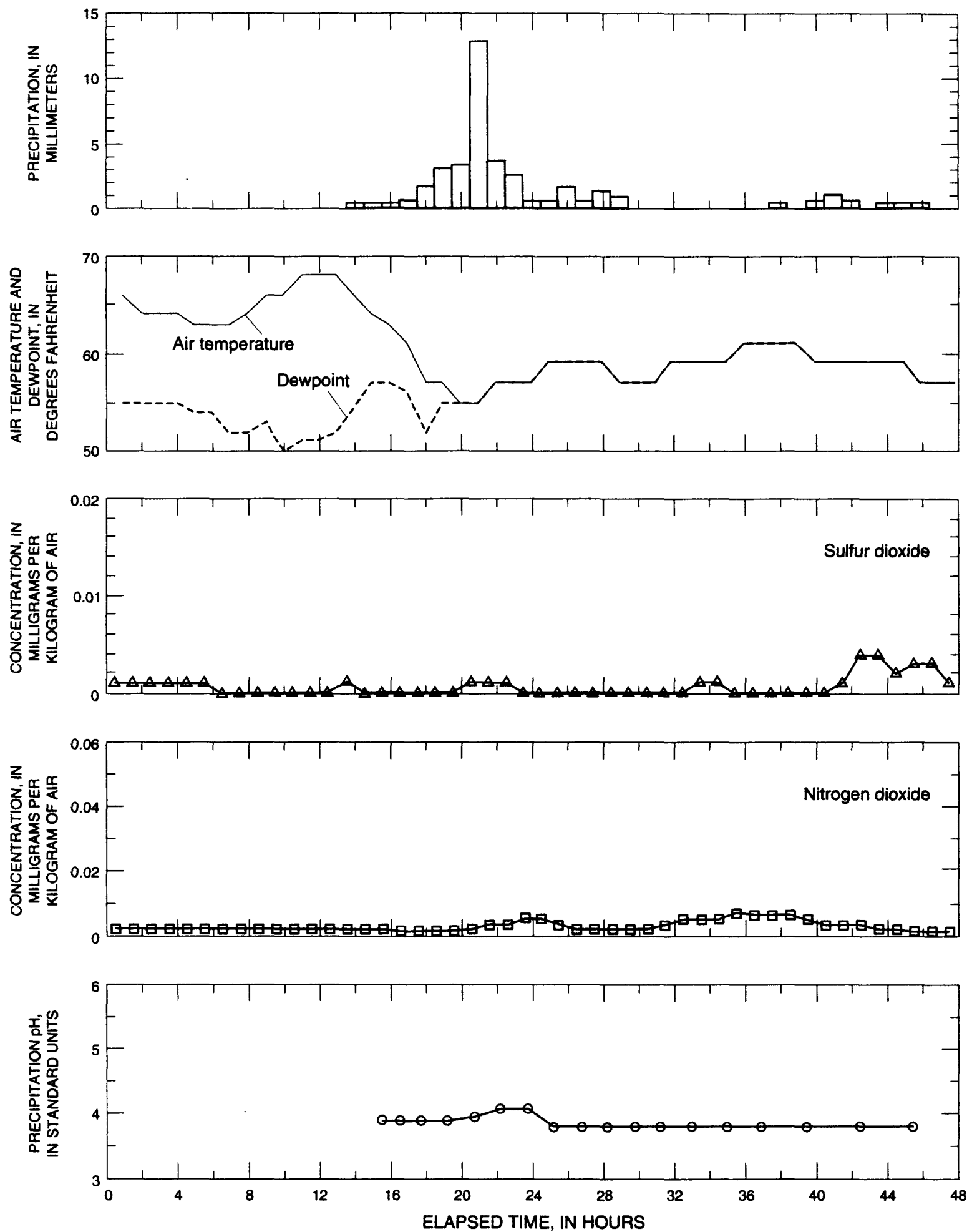
$F$
August 9, 1987
August 10, 1987

Figure 11.--Continued 

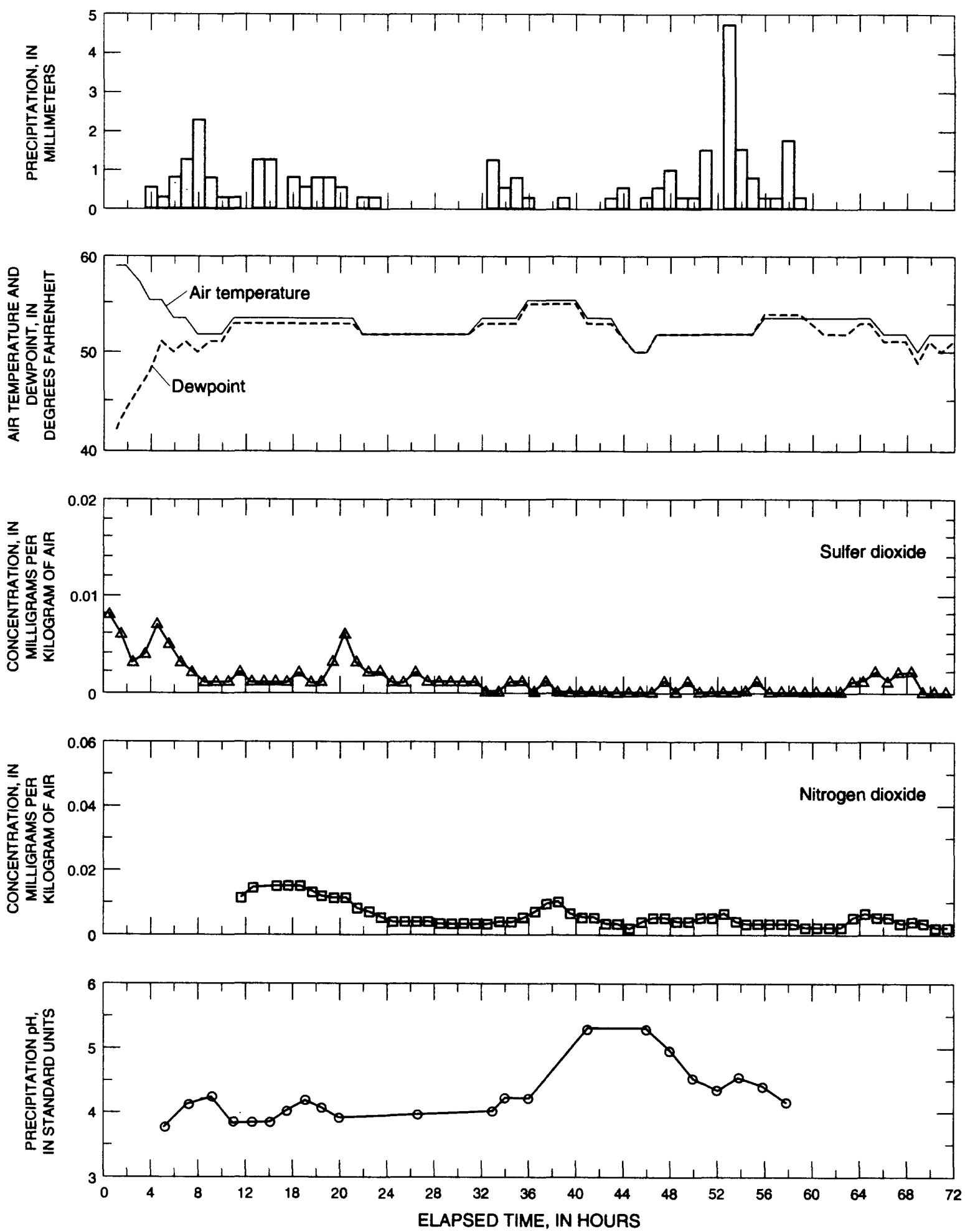

G. $\mid$\begin{tabular}{l|l|l} 
August 27, 1987 & August 28, 1987 & August 29, 1987
\end{tabular}

Figure 11.--Continued 

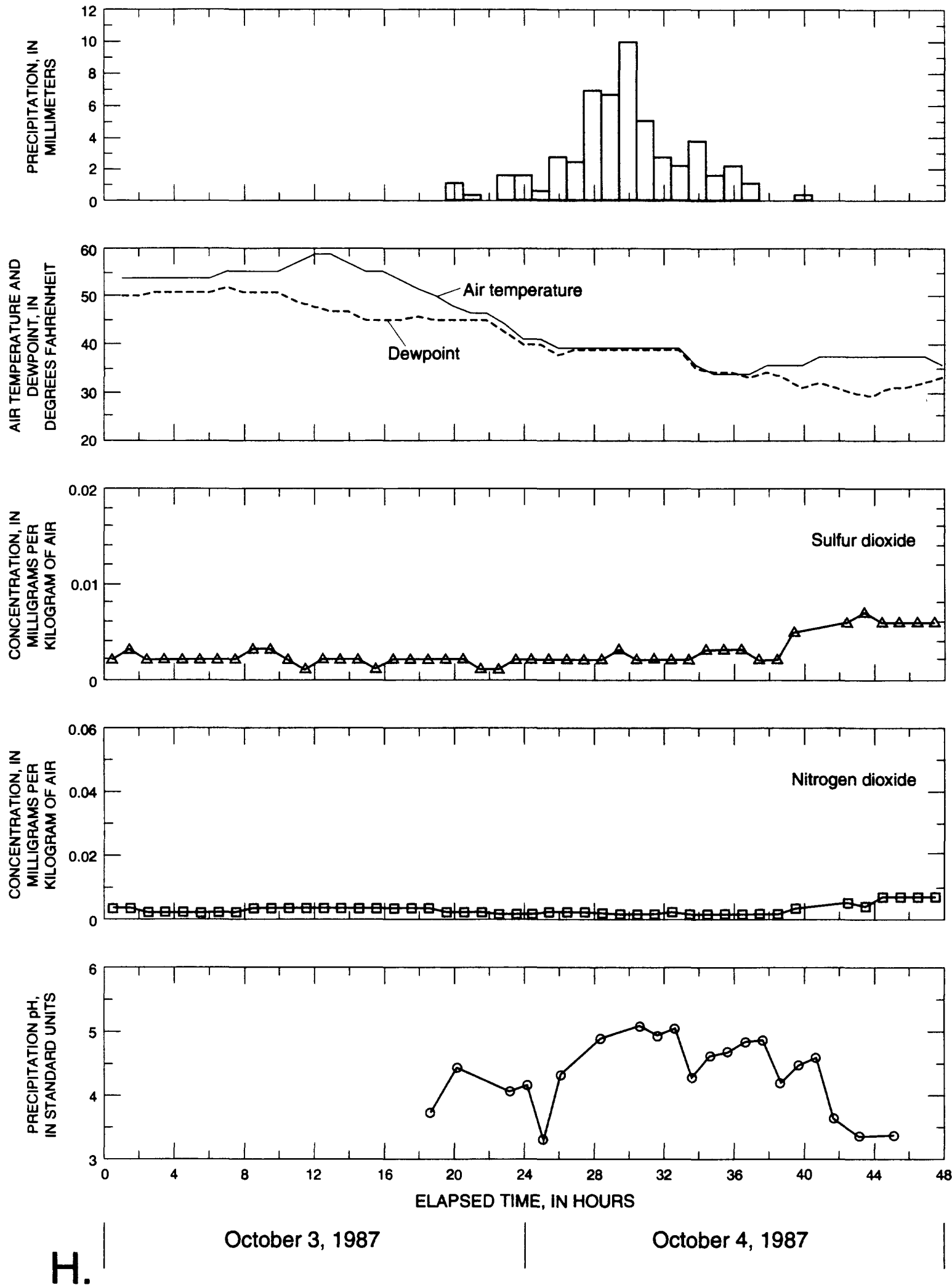

Figure 11.--Continued 
In contrast, particulate material from the August storm was dominated by gypsum but included minor accessory minerals such as quartz, halite, and biotite. Gypsum was not found in any of the other four samples, including the two incremental samples from the same storm; thus, its presence is highly suspect. In each of two incremental samples from the August storm (which represented the middle and ending sections of the storm), garnet was the dominant mineral and quartz was second in abundance. Therefore, garnet and quartz were very small components of the composite sample. Samples from the August storm contained large amounts of pollen.

A striking feature of the filter membranes from the five samples was the presence of a mat of very finegrained organic material. The particle size of this material was less than the resolution of the scanning electron microscope, which was less than $0.01 \mu \mathrm{m}$. The material formed a colloidal mat that bridged the 0.4 $\mu \mathrm{m}$-diameter sized pores of the filter. The mat was visible to the naked eye in all samples, but attempts to identify this material using Laser Ionization Mass Spectrometry-Time of Flight (LIMS-TOF) analysis were unsuccessful. Analysis of the mat on a indium substrate suggested only that the material was polymeric and consisted of a spectrum of carbon-chain lengths. The small particle size and distribution of carbon-chain lengths indicate that some of the particles are composed of only a very few high-formula-weight organic molecules. The material probably belonged to the class of pollutants known as PICs, or products of incomplete combustion (Ken Rahn, University of Rhode Island, oral commun., 1991), associated with mobile (vehicular) sources (Alan Van Arsdale, Northeast States for Coordinated Air Use Management (NESCAUM), oral commun., 1991.)

In summary, the coarse particle (less than $0.4 \mu \mathrm{m}$ ) load of precipitation is not a good indicator of the origin of the air mass associated with a storm. Except under unusual conditions of high surface winds, coarse particles have a short residence time in the atmosphere. Predominantly derived from soil, coarse particles in precipitation result from air entrainment of soil dust and deposition a short distance (less than $100 \mathrm{~km}$ ) from the source.

A recently completed study by Olmez (1989) involved Neutron Activation Analysis (NAA) on coarse- and fine-fraction aerosols to determine airmass source at sites at the Quabbin Reservoir and at Massachusetts Institute of Technology. Hermann and
Olmez (1990) completed a source attribution study of aerosol particulates less than $10 \mu \mathrm{m}$ in size (PM-10) in eastern Massachusetts. On the basis of factor analysis, the predominant PM-10 particulates were attributed to regional coal combustion. Rahn and Lowenthal (1984, 1985) have analyzed aerosols and solid residue from precipitation at a network of sites in the Northeast. They have used arsenic, manganese, selenium, vanadium, and zinc as indicator species to apportion pollutant sources to Midwestern United States, Northeastern United States, or the smelter area of southern Canada. Currently, a project by NESCAUM (Richard Poirot, Vermont Division of Air Quality, oral commun., 1991), which includes a site at Quabbin Reservoir, is investigating the use of the fine (less than $2.5 \mu \mathrm{m}$ ) aerosol fraction for source apportionment. In addition, the U.S. Environmental Protection Agency is using a site at Quabbin for its eastern visibility fine particle network. For this study, fine aerosols (less than $2.5 \mu \mathrm{m}$ ) are collected on filters of various materials to fractionate them into organic and inorganic components.

\section{Selected Storms}

Data from eight storms analyzed for within-storm chemistry variations were insufficient for identifying patterns and a clear correlation between precipitation chemistry and meteorological variables; however, a discussion of three of the storms provides insights and some understanding to the various processes involved.

\section{October 26-27, 1986}

Among the eight storms analyzed, the antecedent ambient air quality, as indicated by concentrations of sulfur dioxide and nitrogen dioxide, was poorest for the storm of October 26-27 (fig. 11). Accordingly, washout processes exerted control on precipitation chemistry. Washout is apparent from a pH near 4.0 at the onset of the storm and a subsequent increase in $\mathrm{pH}$ to near 4.6. Further evidence of washout is the sharp decrease in atmospheric nitrogen dioxide concentration from nearly $0.06 \mathrm{mg} / \mathrm{kg}$ before rain began to less than 0.01 $\mathrm{mg} / \mathrm{kg}$ toward the end of the storm. Likewise, atmospheric sulfur dioxide concentration decreased from 0.015 to $0.002 \mathrm{mg} / \mathrm{kg}$ as a result of precipitation. The distribution of acid inputs relative to water inputs was highly skewed (fig. 11). More than 40 percent of the hydrogen ion was deposited with the first 10 percent of the rain. During the most intense part of the storm, only 
about 10 percent of the total hydrogen ion for the storm was deposited with about 60 percent of the total rain. At the end of the storm, $\mathrm{pH}$ decreased to near 4.2, and 30 percent of the acidity was deposited with the final 10 percent of the rain.

Because washout is associated with a continually decreasing source of acidity, the decrease in $\mathrm{pH}$ at the end of the storm represents a new source of acidity. The October 26-27, 1986 storm was associated with a coastal warm front. Surface-air and dewpoint temperature indicate that a warmer and more humid air mass moved in the region after the storm (fig. 11). The washout observed in the storm probably was associated with the cooler pre-storm air mass. The source of acidity at the end of the storm may be related to rainout from the invading warmer air mass as it entered. Alternatively, the decrease in $\mathrm{pH}$ may have resulted from concentration of solutes by evaporation, as the decrease occurred during a low-intensity period of the storm. The $\mathrm{pH}$ decrease was associated with less than $2.54 \mathrm{~mm}$ of rain that fell during a 10-hour period.

\section{March 30-April 1, 1987}

The March 30-April 1, 1987 storm was the least acidic of all eight storms, with a composite $\mathrm{pH}$ of 5.1; however, $\mathrm{pH}$ of incremental samples at the beginning and the end of the storm was near 4.0 (fig. 11). The low $\mathrm{pH}$ at the beginning of the storm was attributed to washout, whereas the low $\mathrm{pH}$ at the end of the storm was attributed to rainout associated with a new air mass moving into the region. The amount of washout was relatively small, as indicated by the rapid increase in $\mathrm{pH}$ to 5.6. Atmospheric concentrations of sulfur dioxide and nitrogen dioxide, which were relatively low before the storm (fig. 11), indicate a relatively clean atmosphere, thus, the amount of washout was small. The storm was associated with a continental cold front, but most of the rain that fell was dilute. At the end of the storm, however, a new air mass entered the site. This is indicated by a lowering of surface-air and dewpoint temperatures and a sharp decrease in $\mathrm{pH}$ at the end of the storm. This pattern is atypical and is counter to the trend expected from washout. Concurrent with the decrease in $\mathrm{pH}$, the wind shifted from southeasterly to northwesterly. Northwesterly winds bring in more contaminated air, which is reflected in increases in atmospheric sulfur dioxide and nitrogen dioxide (fig. 11).

\section{August 9-10, 1987}

The storm of August 9-10, 1987, was the most acidic of the eight storms considered, with a composite $\mathrm{pH}$ of 3.9. Unlike the other storms, the deposition of acid was uniform throughout the storm (fig. 10). This uniform deposition is consistent with the hypothesis stated above; that is the source of acidic inputs to rainout is continually replenished during a storm. The conclusion that rainout dominated the storm chemistry also is consistent with the path of the storm-the August 9-10 storm was a classic continental lowpressure system that had the potential for transport of large amounts of contaminants into Massachusetts from the industrialized Midwest. The uniform deposition of hydrogen ion indicates that contributions to acidity from washout were limited. In addition, the atmosphere was unusually clean before the storm. Atmospheric concentrations of sulfur dioxide and nitrogen dioxide were much too low for washout to account for the high loading of acid during the August 9-10 storm (fig. 11).

\section{SUMMARY}

Assessing the adverse effects of acidic precipitation on the water bodies of Massachusetts requires an improved understanding of the chemical characteristics of precipitation. This report presents the analysis and findings of data collected from 31 storms at Quabbin Hill in central Massachusetts during October 1986 through December 1987. Although the data from 31 storms are not sufficient to identify clear patterns and relations between precipitation chemistry and meteorological variables, they provide insights and some understanding about the various processes involved.

The 31 storms were divided into two groups based on their paths into the Northeast. Twenty-four storms had a continental path west of the Appalachians. The remaining seven storms had a coastal path east of the Appalachians. The Mann-Whitney nonparametric test was used to test for differences between groups in means of physical and chemical characteristics. These characteristics included precipitation volume, specific conductance, and the concentrations and loads of common chemical constituents. At a 5-percent level of significance, the means of specific conductance and sulfate concentrations for the continental-storm group were greater than the corresponding means from the coastalstorm group. Specific conductance was an adequate surrogate for many of the chemical constituents. These test results would indicate that precipitation from storms 
traveling from the Midwest is more acidic than precipitation from Atlantic seaboard storms. However, the loads of hydrogen ions and other common chemical constituents from both groups were not significantly different probably because the continental storms produced less precipitation volume.

The within-storm variability of acidic deposition was evaluated by comparing accumulated hydrogenion loading with accumulated precipitation depth from eight storms. The $\mathrm{pH}$ of the composite samples of the storms ranged from 3.9 to 5.1 . Based on relatively higher hydrogen-ion loading at the beginning of the storms, seven of the storms showed evidence of washout during their early stages; however, the hydrogen-ion deposition of the eighth storm (also the most acidic) was evenly distributed throughout the storm indicating that rainout dominated.

Data from these same eight storms were used to compare ambient atmospheric concentrations of sulfur dioxide and nitrogen dioxide before, during, and after the storm with within-storm $\mathrm{pH}$ and precipitation. In seven of the storms, atmospheric sulfur dioxide and nitrogen dioxide concentrations decreased in the early stages. However, these concentrations increased for all storms once the storm had ended. For three of the storms, concentrations of sulfur dioxide and nitrogen dioxide were higher during the 24-hour period after the storm than during the 24-hour period before the storm.

Particulates collected in $0.4-\mu \mathrm{m}$ pore-size filter membranes from composite and incremental precipitation samples of three storms of April 12-13, 1987, August 9-11, 1987, and September 30, 1987 were analyzed for composition. Biotite was the dominant inorganic material in the April and September storms. Gypsum was the dominant inorganic material in the August storm. Incremental samples from the same storm were dominated by garnet. Because of the large particle size, the origin of these particulate materials was most likely local. All five of the filter membranes showed the presence of a mat of very fine-grained (less than $0.01 \mu \mathrm{m}$ ) polymeric organic material.

\section{REFERENCES CITED}

Babich, Harvey, Davis, D.L., and Stotzky, Guenther, 1980, Acid precipitation--causes and consequences: Environment, v. 22, no. 4,10 p.

Beamish, R.J., and Van Loon, J.C., 1977, Precipitation loading of acid and heavy metals to a small acid lake near Sudbury, Ontario: Journal of the Fisheries Resources Board of Canada, no. 34, p. 649-658.

Chas T. Main, Inc., 1986, MASS DEQE-acid deposition air quality monitoring program Quabbin summit site June 1985 - May 1986 summary report: Report for Commonwealth of Massachusetts, Department of Environmental Quality, p. 1-41.

Cogbill, C.V., and Likens, G.E., 1974, Acid precipitation in the northeastern United States: Water Resources Research, v. 10, no. 6, p. 1133-1137.

Cowling, E.B., 1982, Acid precipitation in historical perspective: Environmental Science and Technology, v. 16, no. 2, p. 110A-123A.

Drever, J.I., 1988, The geochemistry of natural waters (2d ed.): Englewood Cliffs, N.J., Prentice Hall, 437 p.

Glass, N.R., Arnold, D.E., Galloway, J.N., Hendrey, G.R., Lee, J. J., McFee, W.W., Norton, S.A., Powers, C.F., Rambo, D.L., and Schofield, C.L., 1982, Effects of acid precipitation: Environmental Science and Technology, v. 16 , no. 3 , p. $162 \mathrm{~A}-169 \mathrm{~A}$.

Hermann, Diane and Olmez, Ilhan, 1990, Source attribution studies in eastern Massachusetts, in Proceedings of the Annual Meeting and Exhibition of the Air and Waste Management Association, 83rd, Pittsburgh, Pa., June 24-29, 1990, no. 90-78.2, 16 p.

Iman, R.L., and Conover, W.J., 1983, A modern approach to statistics: New York, Wiley, 497 p.

Junge, C.E., 1963, Air chemistry and radioactivity: New York, Academic Press, p. 289-306.

Likens, G.E., Wright, R.F., Galloway, J.N., and Butler, T.J., 1979, Acid rain: Scientific American, v. 241, no. 4, p. 43-51.

Lindberg, S.E., Harris, R.C., Turner, R.R., Shriner, D.S., and Huff, D.D., 1979, Mechanisms and rates of atmospheric deposition of selected trace elements and sulfate to a deciduous forest watershed: Oak Ridge National Laboratory, Environmental Sciences Division, no. 1299, $550 \mathrm{p}$.

Olmez, Ilhan., 1989, Instrumental neutron activation analysis of atmospheric particulate matter, in Lodge, J.P., ed., Methods of air sampling and analysis: Boca Raton, Fla., Lewis Publishers, p. 143-150.

Rahn, K.A., and Lowenthal, D.H., 1984, Elemental tracers of distant and regional pollution aerosols: Science, v. 223, p. 132-139. 
Rahn, K.A., and Lowenthal, D.H., 1985, Pollution aerosol in the Northeast-Northeastern-Midwestern contributions: Science, v. 228, p. 275-284.

Schindler, D.W., 1988, Effects of acid rain on freshwater ecosystems: Science, v. 239, p. 149-157.

Shortle, W.C. and Smith, K.T., 1988, Aluminum-induced calcium deficiency syndrome in declining red spruce: Science, v. 240, p. 1017-1018.

Turk, J.T., 1983, An evaluation of trends in the acidity of precipitation and the related acidification of surface water in North America: U.S. Geological Survey Water-Supply Paper 2249, 18 p.

U.S. National Weather Service, 1986, Daily weather mapsWeekly series, October 20-26, 1986: Washington, D.C., U.S. Department of Commerce, $8 \mathrm{p}$.
U.S. National Weather Service, 1987a, Daily weather maps-Weekly series, March 30-April 5, 1987: Washington, D.C., U.S. Department of Commerce, 8 p. 1987b, Daily weather maps-Weekly series, August 3-9, 1987: Washington, D.C., U.S. Department of Commerce, 8 p.

Wolff, G.T., 1989, Estimates of regional contributions to wet acid deposition in western Massachusetts during the summer of 1984: Atmospheric Environment, v. 23, no. 3, p. 595-601.

Wolff, G.T. and Korsog, P.E., 1989, Atmospheric concentrations and regional source apportionments of sulfate, nitrate, and sulfur dioxide in the Berkshire Mountains in western Massachusetts: Atmospheric Environment, v. 23 , no. 1, p. $55-65$. 